\title{
The Market Trajectory of a Radically New Product: E-Cigarettes
}

\author{
Mickey M. Kislev ${ }^{1} \&$ Shira Kislev ${ }^{2}$ \\ ${ }^{1}$ Ramat Gan, Israel \\ ${ }^{2}$ Smoke-Free Israel, Ramat Gan, Israel \\ Correspondence: Mickey Kislev, P. O. Box 10350, Ramat Gan 5200203 Israel. E-mail: \\ mickeykislev@researchgap.ac
}

Received: October 25, 2020

Accepted: November 26, 2020 Online Published: November 28, 2020

doi:10.5539/ijms.v12n4p63

URL: https://doi.org/10.5539/ijms.v12n4p63

\begin{abstract}
The study analyzes the diffusion of electronic cigarettes as an innovation, as well as how industry, society, and the individual affect its market dynamics. The study is based on five surveys conducted during the years 2017-2019, and including participants of all ages (age 12 to 80 and beyond). The article describes indicators for evaluating the sustainability of a really-new product like electronic cigarettes, following the market trajectory of this product as it sets its dominant design and shapes the use-system for the product type from now onward. This process has two phases: trial and adoption. The probability of each nicotine product type's adoption is different, depending on the prevalence of trials of that product among the population. The results of e-cigarette trials and additional indicators reveal the point (critical mass-point) where social influence outweighs rational evaluation by the individual regarding nicotine products. By using triers' prevalence as the indicator for measuring an entry of really-new product into the market, the authors could identify the sustainability of that really-new product at a much early phase. Therefore, the prevalence of triers can be used as a predictor for the diffusion rate of an innovative product in a certain population and should be measured. The authors also propose a regression model that estimates the prevalence of triers based on the extent of users in the population.
\end{abstract}

Keywords: demerit good, electronic cigarette, innovation, diffusion, nicotine

\section{Introduction}

Research on the market diffusion process of an innovation is limited by opportunities to study the entrance of a really-new product. The entry of electronic cigarettes into the nicotine market during the first years of the 3rd millennium (Grana, Benowitz, \& Glantz, 2014), provides a unique opportunity to study market dynamics following the launch of an innovation. The results of this study could be also valuable for research in public health and tobacco control.

The introduction of electronic cigarettes provided an opportunity to review current theories from the field of business marketing on the adoption process of an innovation, and to try to proceed toward a more detailed understanding of the conditions under which a consumer-packaged goods (CPG) enters the market. Nicotine products are defined as 'demerit goods' (Musgrave, 1959) (Note 1). Otherwise, the consumption of nicotine substances resembles the consumption of other CPG such as soft drinks or chocolate.

The new type of ENDS (electronic nicotine delivery system) products known as electronic cigarettes (Ayers, Ribisl, \& Brownstein, 2011) can be defined as a really-new product (def. Urban, Weinberg, \& Hauser, 1996). In contrast to other non-combustible products, they contain only liquid nicotine and no tobacco. According to a report by Euromonitor International (2017), the market share of electronic cigarettes in 2014 was almost undetectable in Israel (MSH of $<0.1 \%$ ), and continued to be negligible in the following years (MSH of ca. $0.5 \%$ in 2016). Commercial activities surrounding electronic cigarettes during 2017-2018 (Israel Ministry of Health, 2019) indicated the expansion of their use beyond a negligible rate. Recent equivalent data on marketing developments in additional countries (Hammond et al., 2019; Huang et al., 2019), indicates that a similar change occurred all over the western hemisphere. The accelerated diffusion of this innovative product provides a unique opportunity to witness the process as it happens.

Tracing the stages of a product's diffusion in its target audience according to the scale of active adopters of that product is accepted methodology (e.g., Bartels \& Reinders, 2011; Im, Mason, \& Houston, 2007; Rogers, 2003; Taylor \& Todd, 1995; Wood \& Swait, 2002). However, researchers have paid little attention to the trial stage, as 
well as to the possibility of a trial rejection by consumers. The current study shows that the rate of active adopters is only the tip of the iceberg, and that below the surface, unseen until now, lies the rest of the market in the form of triers who have not continued their experience at this stage. The authors also suggest a regression model, which can predict the prevalence of triers in the population based on the extent of users of the same product.

\subsection{Study Goals}

The aim of this study is to analyze the diffusion of a new consumer product, as the influence of industry, society, and individual consumers shape its market dynamics. We view the entry of the electronic cigarette as a really-new product to be an opportunity to analyze the nicotine market, and to understand its market dynamics into the future by employing three perspectives: the industry point of view, sociological approaches, and analysis of individual cognition.

\section{Literature Review}

The entry of a new product into the market starts when an industry offers the public a novel service, which the public can either accept, by purchasing the product or ignore (Wasson, 1974).

\subsection{The Industry Perspective}

The losses suffered by several nicotine products manufacturers in 1982-1983 following tax increases were a sign for the industry of an end to the golden age of profit and the beginning of a long period of decline (cf. Albert, 1984). The nicotine industry needed to reverse its market dynamic from decline to growth by creating a new category of nicotine products (cf. Urban et al., 1996). Such a really-new product must have the following qualities (Aggarwal, Cha, \& Wilemon, 1998):

- It is incomparable with any other current product types on the market;

- It sets standards for future innovations;

- It forces consumers to invest considerable efforts to learn how to use it;

- It is accompanied by complementary products unmatchable by the current product types on the market;

- It is perceived, at first, as very risky, due to the lack of performance evidence;

- It attracts considerable attention.

The very definition of innovation as a new type of product also rests in the risk it poses for the manufacturer: the risk of market cannibalism of the company's existing products by the innovative product. The manufacturer can define and promote its innovative product as an extension of an existing product, which can lead to a cannibalization of the market by the innovative product (Johnson \& Jones, 1957). For that reason, market leaders reveal a reluctance to adopt new ideas, preferring stability (“don't rock the boat"). Larger companies have more to lose than small companies (Wasson, 1974) and are usually forced to adopt the new product after it is launched by other less significant competitors and proves to be a success (de Kluyver, 1977).

An additional risk is a misjudgment by the manufacturer's experts on the actual innovativeness of the product and its technology. A product could appear as "revolutionary" to experts but is perceived by the public as almost identical to its equivalent or predecessor products (Wasson, 1974) (Note 2). 


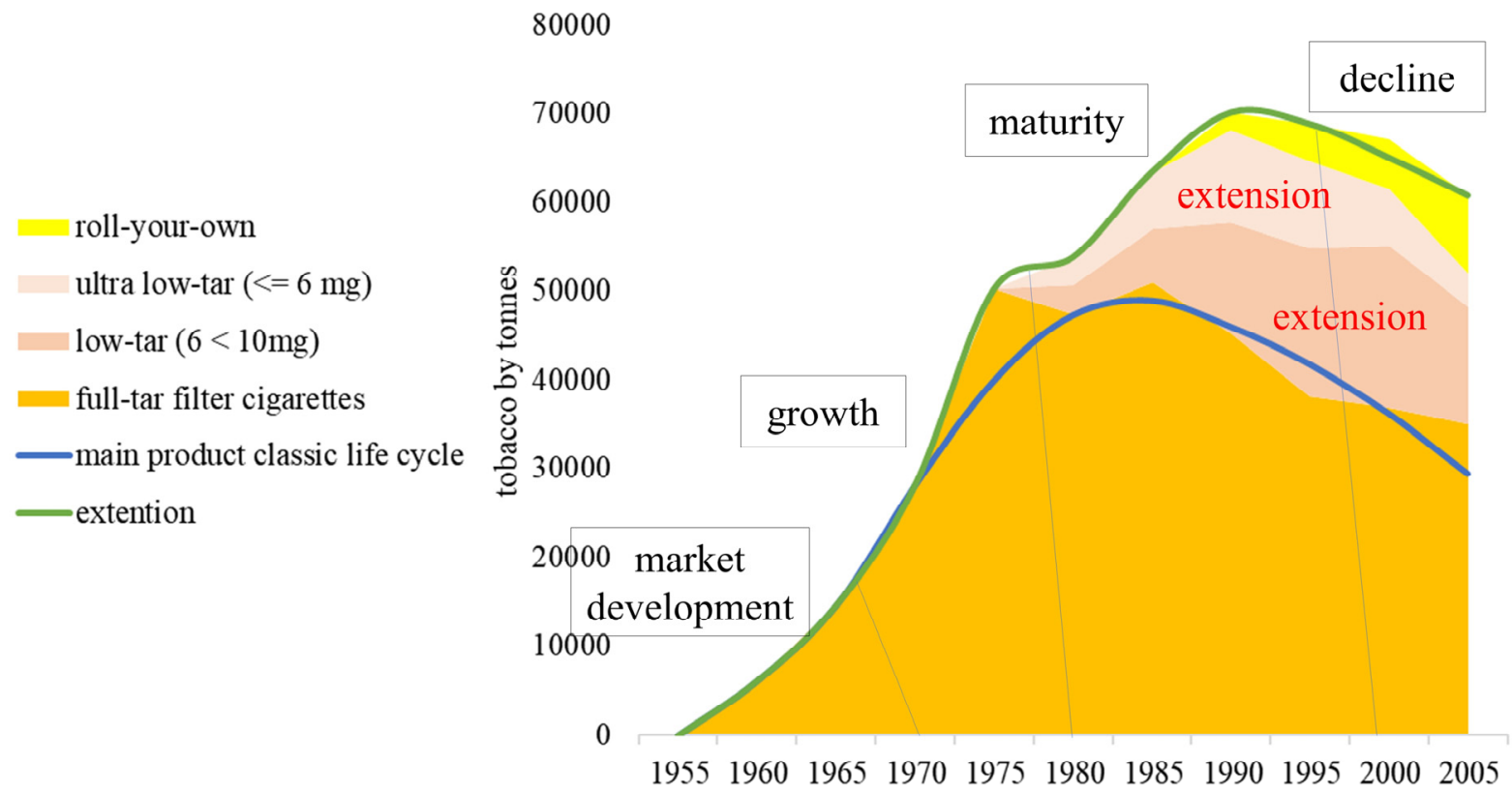

Figure 1. The product life cycle of filter cigarettes with its extensions in France

Note. Based on data of Hill $(2004,2015)$.

This was the case for developments in the nicotine market (illus. Figure 1). The market leaders - Philip Morris International, British American Tobacco, and R. J. Reynolds - were under pressure to produce a new type of nicotine product to replace the declining combustible cigarette, but the breakthrough was made by a small company named Pax Labs, which now is known as "JUUL Labs." Only then did the market leaders introduce a product similar to the successful design of JUUL.

\subsection{The Market Reflection-The Product Life Cycle Model}

Several scholars have noted the product cycle dynamic of cigarettes, defining them as a product in a stage of decline (Thun, Peto, Boreham, \& Lopez, 2012; Vardavas \& Agaku, 2015), based on the model offered by Alan Lopez, Neil Collishaw and Tapani Piha (1994), which describes the dynamic using the language of disease. The nature of nicotine products is to act as a commodity because that is what they are. The economic equivalent to the epidemiological model of Lopez, Collishaw and Piha is the "Product life Cycle" model formulated by Theodore Levit (cf. Crompton \& Hensarling, 1978; Enis, La Garce, \& Prell, 1977; Levitt, 1965; Polli \& Cook, 1969; Wasson, 1974), which goes through these four stages:

- Market development: The new product is first launched into the market, before there is a proven demand for it, and before its qualities have been fully demonstrated. At this stage, the rate of sales is low.

- Market growth: Demand begins to accelerate, and the total market expands rapidly.

- Market maturity: Demand reaches stability as new purchases are based on needs for product replacement and population growth.

- Market decline: The product begins to lose its attraction among its current consumers and sales gradually decline. 
market development $\square$ growth $\square$ maturity decline -classic product life cycle

60000

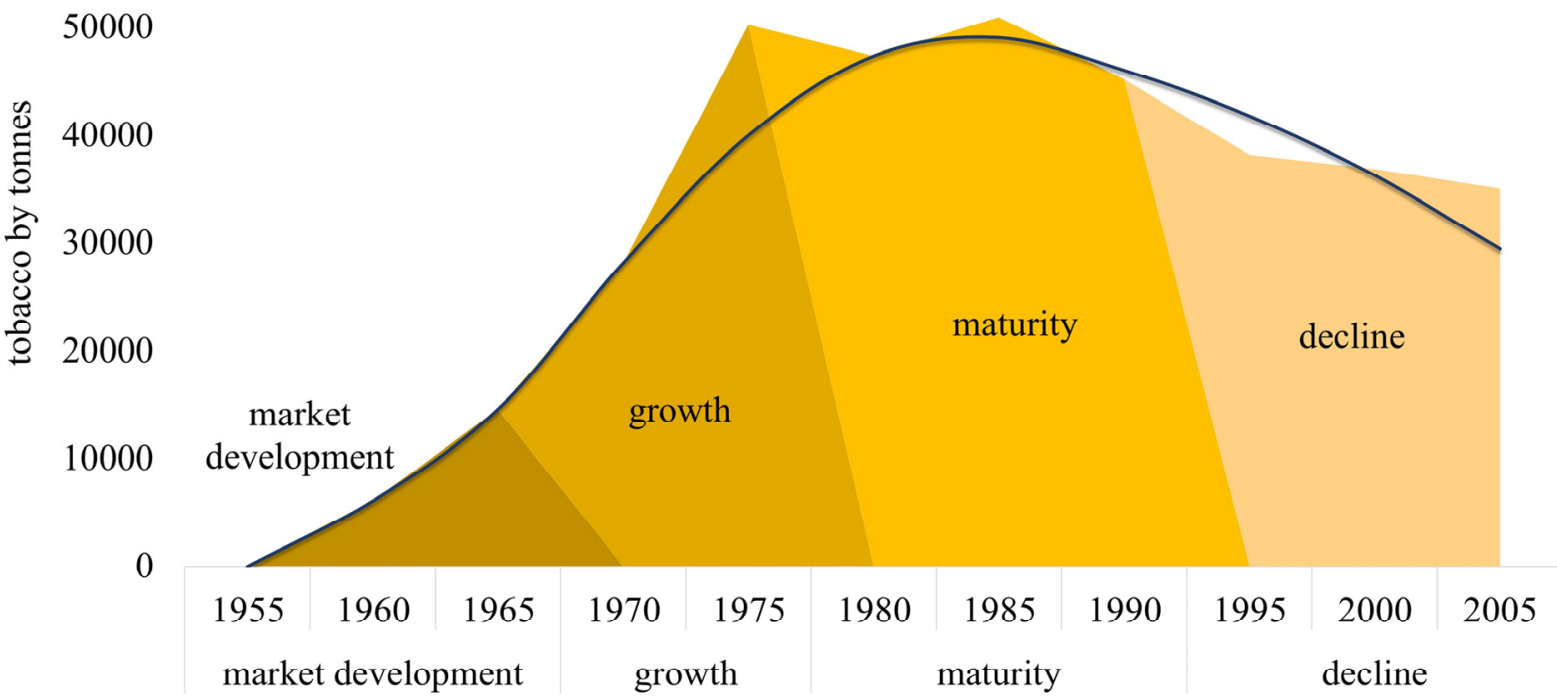

Figure 2. The product life cycle of filter cigarettes in France base on Levitt's model (Levitt, 1965).

Note. Based on data of Hill, 2004, 2015.

Sales of nicotine products follow the market dynamic anticipated by Levitt's model (Figure 2). The basic indicator of the future potential of the market, according to the product life cycle approach, is the population, which did not try the product even once. Once the product has been tried at least once by almost all the population, its potential for market growth is nil. Sales of the product will start to decrease, as other really-new products enter the market for the same need (illus. Figure 3), and regular consumers begin to abandon the product for a more innovative substitute (Saviotti, 2002), creating an endless cycle of industrial progress (cf. Phillips, 2016; Schumpeter, 2003[1950]). 


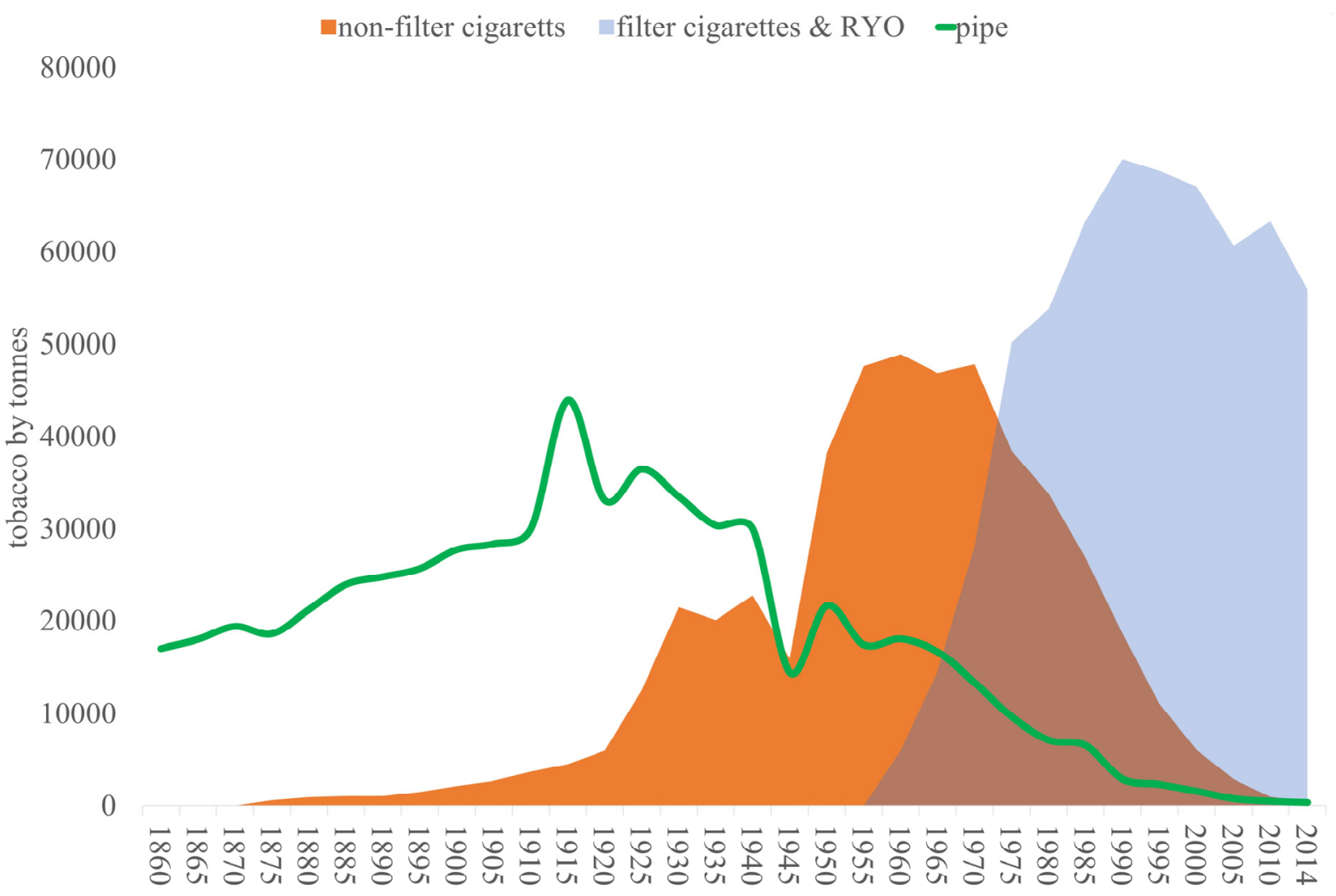

Figure 3. Product life cycles of selected categories of nicotine products in France

Note. Based on data of Hill, 2004, 2015.

By the end of the 2nd millennium, the filter cigarette and its extensions entered the stage of decline, with consumers also abandoning all other types of nicotine products and leaving the industry with just one profitable segment (Note 3). This development reduced the size of the nicotine market back to the pre-filter cigarette period. After 150 years, the life cycle of these second industrial revolution products (Note 4) entered its decline stage (illus. Figure 4). 
120000

- cigar \& cigarelles $\square$ snuff \& chew $\square$ pipe $\square$ non-filter cigaretts $\square$ filter cigarettes \& RYO

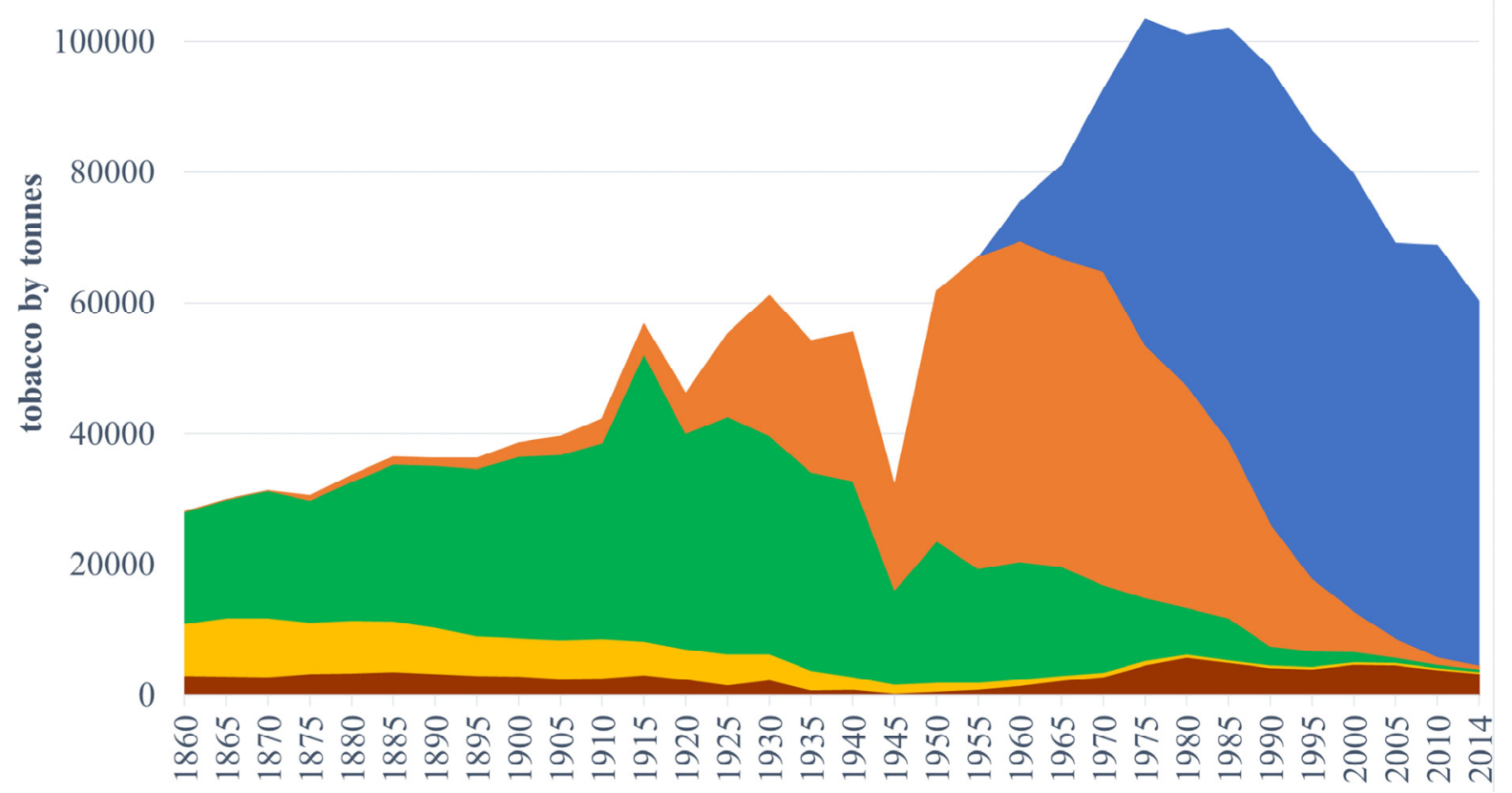

Figure 4. The product life cycle of selected categories of nicotine products aggregated in France

Source: Hill, 2004, 2015.

As predicted by Judith Mackay and Neil Schluger, the decline of the combustible cigarette was not the end of the game, but rather a sign for the wave of new nicotine products which provide alternative means of nicotine delivery, such as electronic cigarettes (Mackay \& Schluger, 2015).

\subsection{Public Response}

Two disparate approaches have developed over the years for the analysis of individual consumers' responses to the launch of a really-new product: The first sets store by individual rational evaluation; yet, that rational evaluation is overpowered by social influence among individuals who are insecure about their social status (Bourne, 1956). The second approach emphasizes the influence of personality on innovativeness and consuming behaviour, classifying different personalities according to their tendency for innovativeness (e.g., Im, Bayus, \& Mason, 2003; Rogers, 2003; Wood \& Swait, 2002).

\subsubsection{The Individual Perspective}

The rational evaluation approach is based on the assumption that the consumer has a constant need for a product group attribute, but each consumer differs in his/her "most preferred" product (Lancaster, 1990, 1991; Wasson, 1974) (Note 5). The product is, in fact, the perception of a desire-set; certain needs which it aims to satisfy. The active consumers in the market are those who rank their desire-set as close as possible to the product perception (Kamakura \& Novak, 1992; Lancaster, 1966; Menger, 1871). Each consumer has a different desire-set since it is determined by his/her personality and motivations (cf. Eysenck, 1998 [1947]; Mowen, 2000).

Over the years, many variables - such as the need for a change, risk, or the extent of practice needed for the use of the new product - were proposed as influencing the individual desire-set (e.g., Brown, Massey, Montoya-Weiss, \& Burkman, 2002; Chatterjee \& Eliashberg, 1990; Clark, 1985; Hiebert, 1974; Meenaghan \& O’Sullivan, 1986; Miller, 1987; Mowen, 2000; Nelson \& Winter, 1982; Ostlund, 1974; Parasuraman, 2000; Raju, 1980; Steenkamp \& Gielens, 2003; Wood \& Swait, 2002). The main instrument for the rational evaluation of these considerations is information (Moreau, Markman, \& Lehmann, 2001; Olshavsky \& Spreng, 1996). Innovators need less information than imitators for filling the knowledge gap, which they do use logic, skills, or extensive familiarity since they do not have a reference to imitate (Cohen \& Levinthal, 1990; Saviotti, 2002).

The information processing, as described above, takes place primarily during the early phase of symbolic 
adoption, defined by Gerald Klonglan and E. Walter Coward as the stage of decision-making before trying the product for the first time (Klonglan \& Coward, 1970). They distinguish the early phase of decision making from the acquisition phase (illus. Figure 5) (Note 6).
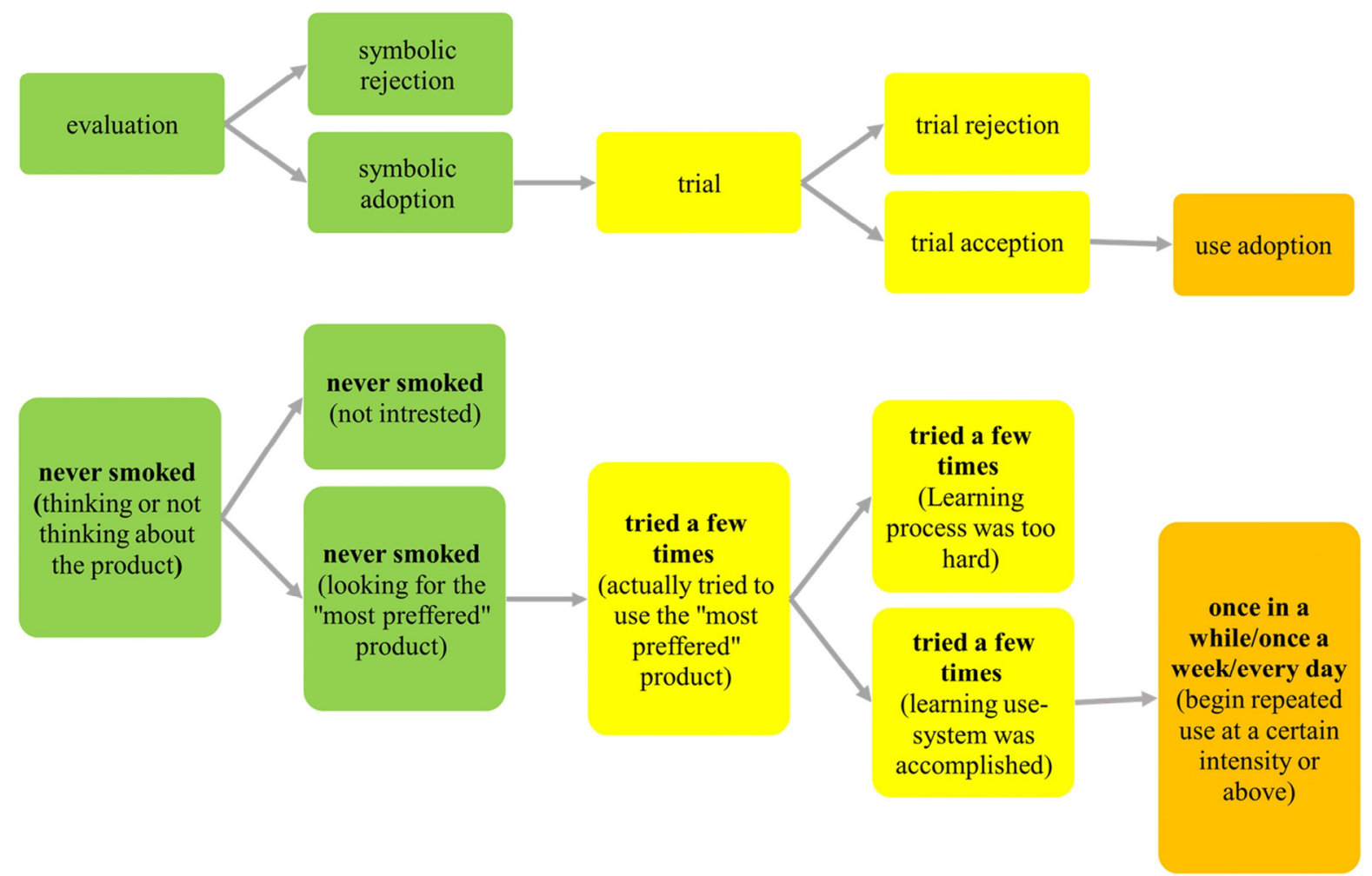

Figure 5. Comparison between a generic consumption flowchart and nicotine consumption terminology (Note 7)

Sources: Klonglan and Coward, 1970; Mittelstaedt, Grossbart, Curtis, and Devere, 1976.

An individual will not try a nicotine product (never-user) when none of the perceptions of a given type of a nicotine product (combustible cigarette, electronic cigarette, pipe, hookah, etc.) correspond with the desire-set that is characteristically highly important for that individual's population group (Wasson, 1974). The individual develops confidence in the new product during the first attempt to use it (Ram \& Jung, 1991).

Those who tried a nicotine product a few times and did not proceed to smoke regularly (triers) did not develop a nicotine dependency. They are either in the stage of deciding whether to accept or reject the product, or they have already rejected the product. Wasson describes these attempts as a learning period of the use-system for the consumer, a period, which demands effort and practice without the reward of satisfaction from the product. The trier needs consistent encouragements, to be motivated enough to finish his/her training. According to Wasson, the vast majority of triers succeed in mastering the technique to the level of satisfaction. Nonetheless, the learning process in the use of a new product is a barrier, which sets back the future market growth of the new product. The sign of the completion of the learning period to the point of satisfaction is the transition of the subjects from periodic use to repetitive use. Such consumers can be classified as acquisition adopters (Wasson, 1974).

Those who reach the point of adoption and are satisfied with the product will stick with that product over new alternatives, based on their positive experience with it (Bauer \& Wortzel, 1966). Less satisfied consumers will look for new alternatives, which satisfy them and which blend into the current technological regime (Geels, 2005; cf. Wasson, 1974). They will decide to try an innovation only if they are convinced based on their information gathering that the new product is a better match to their desire-set than their current product (Olshavsky \& Spreng, 1996).

Beyond these less satisfied consumers who continue to search for satisfaction, it is assumed, although not yet proven, that innovations also expand the market size, as new consumers who rejected other products for the same 
need find the new innovative product to be a match for their desire-set (Saviotti, 2002; Thorelli \& Burnett, 1981) The entry of additional types of products enlarges the variety of product types in the market and consequently enlarges the different types of consumers who consume the product-group (Crawford, 1972; Johnson \& Jones, 1957; Wasson, 1974).

This is also the point of entry to addiction. Nicotine dependency evolves as the user proceeds from the trial stage to the adoption stage (DiFranza et al., 2000) (Note 8). This shift is the point where the user passed his/her last exit point from the market. The addictive influence of this product-group makes it extremely difficult for users who reach the "adoption stage" to reject their own adoption (Adams \& Livingstone, 2015; Rogers, 2003).

\subsubsection{The Social Perspective}

Everett Rogers in his book Diffusion of Innovations layout the definitive terminology and definitions for the theory of diffusion (Rogers, 2003): He describes five intrinsic levels of inclination to adopt an innovation for each member of a social system (Rogers, 2003; Rogers \& Beal, 1958) (Note 9): innovators; early adopters; early majority; late majority; and laggards (illus. Figure 6).

His variable for measuring the diffusion rate of an innovation was the number of individuals who either completely adopted the product, or were, at least, close to complete adoption (Rogers, 1958). The stages in his model focus on adoption while ignoring the rate of triers as an equivalent indicator. In practice, Rogers ignores the earlier work by Ryan and Gross (1950), who observed both the rates of triers and the rate of adopters. Ryan and Gross found a reverse correlation between the prevalence of adoption and the trial period. Moreover, the diachronic analysis by Ryan and Gross reveals that low adoption rates of a product could change over time, as the rate of use increases (ibid.).

At the stage where laggards begin to adopt the innovation, its use is so common that the product is considered to be a mandatory standard, and has already begun to be replaced by the next advanced product among innovators (Rogers \& Shoemaker, 1971). The innovators tempt to try to satisfy the same needs by using an innovative product suitable to the current technological regime, and by that creating an endless cycle of innovation (Phillips, 2016).

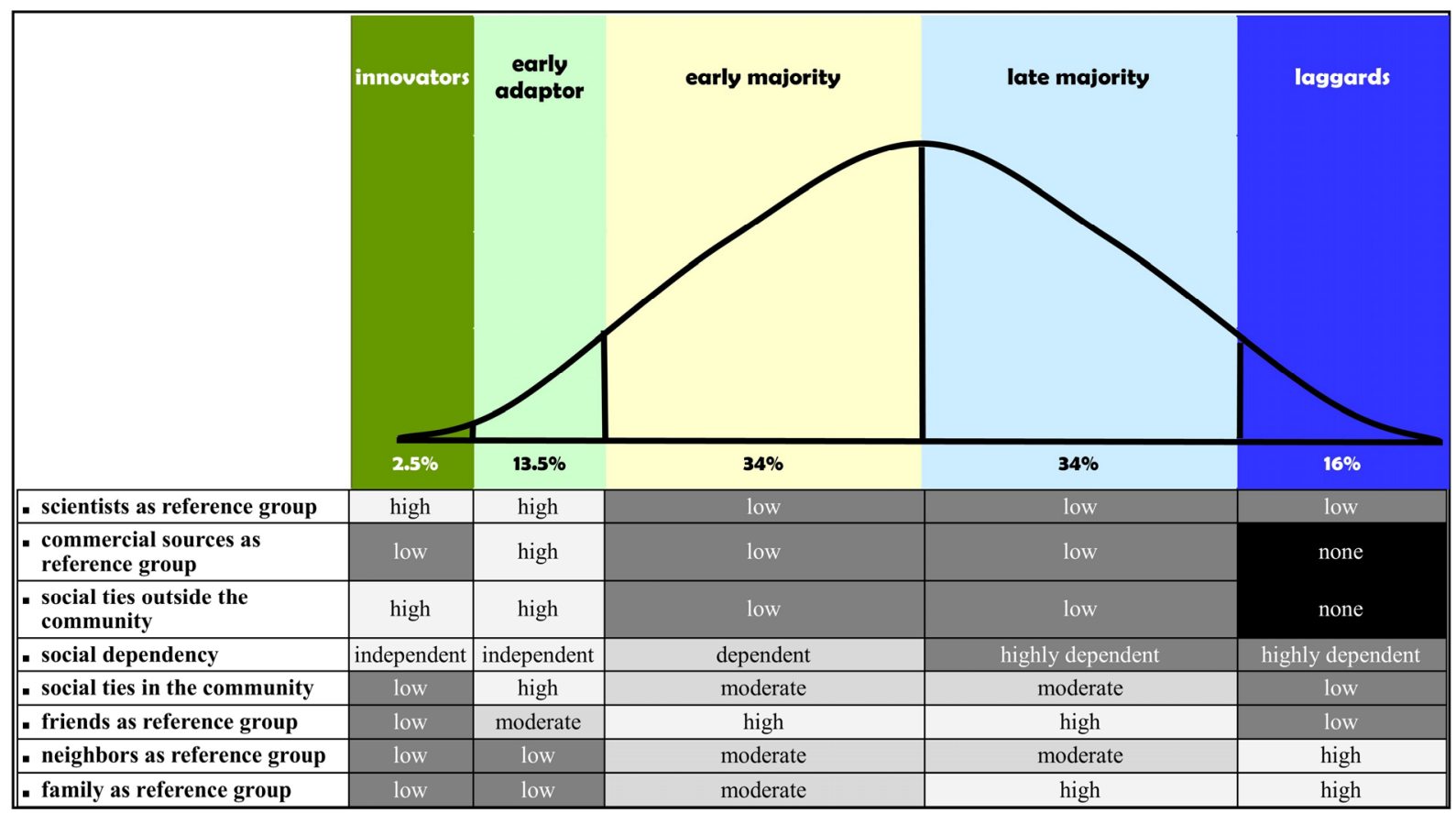

Figure 6. Adoption categories based on Rogers' definitions

Sources: Lionberger, 1954; Rogers, 1958; Rogers and Beal, 1958; Ryan, 1948; Ryan and Gross, 1943, 1950; Wilkening, $1950,1951,1952$. 
Ethnocentrism and collectivism are found to be negative influences on the innovativeness of the individual, regardless of his/her personality and psychological characteristics. Social influence on an individual is so comprehensive that it is not just additional value in an individual desire-set, but rather, it pushes the desire-set of the individual towards a preference for more traditional motivations conforming to existing social values (Steenkamp, ter Hofstede, \& Wedel, 1999). As a result, the rate of social dependence reversely correlated with the individual tendency to adopt innovations. A higher social dependency means a more conservative approach by the individual (Wilkening, 1950).

The social surroundings are the individual peer-groups of friends within the entire community (Lionberger, 1954). An innovation can be condemned in one peer-group while being highly appreciated in another peer-group. Therefore, the tendency to adopt a certain innovation by the individual depends mainly on the opinion of that individual's closest friends (Warde, 2002).

\section{Method}

\subsection{Data Collection and Sample}

The research included five online surveys conducted between October 2017 and May 2019, among the Jewish population in Israel, using an online survey panel, "Midgam Project Panel." The surveys were conducted as follows:

Table 1. Stages of data collection

\begin{tabular}{llll}
\hline \# Dates & Sample & Ages & Main Subject \\
\hline $\mathbf{1}$ October 31-November 3, 2017* & 844 & $12-64$ & The framing of nicotine products in the population \\
$\mathbf{2}$ April 30-May 3, 2018** & 1710 & 12 and above & The correlation between price and consumption of nicotine products \\
3 August 5-August 7, 2018 & 431 & $12-18$ & The effect of the school environment on smoking behaviour among youths \\
4 October 29-November 8, 2018 & 406 & $12-18$ & The effect of advertainment of nicotine products on youth \\
\hline S April 19-May 7, 2019 & 2300 & 12 and above & E-cigarette market penetration, and the consumer response \\
\hline \multicolumn{2}{c}{ Note. * A small supplement was conducted on November 12, 2017; ** Small supplement was conducted on May 22, 2018. }
\end{tabular}

Each participant entered his/her demographic data as part of the registration to the panel. The participants' collected answers were downloaded as CSV files and uploaded to an R platform (R Core Team, 2020) for tagging and preparation. The final survey was completely analyzed in R, including statistical calculation and the production of outputs. The analyses were weighted to be nationally representative by age and gender, based on the national demographic estimates of the Central Bureau of Statistics of Israel for 2017 (Israel Central Bureau of Statistics, 2018, Pl. 2.3).

The first survey in November 2017 was used as a preliminary observation of the state of smoking in the population, an experimental arena for understanding the right approach to measuring the behaviour and consumption of smoking products.

The questionnaire was based on the formal questions used in the Global Youth Tobacco Survey 2002 (GYTS, 2002). Since the GYTS questionnaire was meant for adolescents, it was unclear whether the formulation of the questions on the intensity of use and the product types which were tried and used was equally suitable for adults. Since both adolescents and adults consume nicotine products, the authors had to develop a measuring method suitable for both groups. This method was developed based on the outcomes of the previous surveys carried out prior to the last wave of Apr-May 2019. So that each survey sample could be compared to the previous one, the randomized samples of all five waves were designed to represent the same population. Although the data collected in the first four surveys is of limited value to the issues presented here, the contribution of those waves to the development of the methodology was significant. Each wave was conducted after a thorough study of the results from the methodological adjustments to the previous wave, until reaching the optimal method for researching the issues presented in this paper. 
Table 2. Sample demographic weight, by survey waves

\begin{tabular}{|c|c|c|c|c|c|}
\hline & Oct-Nov 2017 & Apr-May 2018 & Aug 2018 & Oct-Nov 2018 & Apr-May 2019 \\
\hline \multicolumn{6}{|l|}{ Gender: } \\
\hline Female & $51.8 \%(437)$ & $56.4 \%(965)$ & $59.4 \%(256)$ & $52.0 \%(211)$ & $52.4 \%(1205)$ \\
\hline Male & $48.2 \%(407)$ & $43.6 \%(745)$ & $40.6 \%(175)$ & $48.0 \%(195)$ & $47.6 \%(1095)$ \\
\hline Total & $100.0 \%(844)$ & $100.0 \%(1710)$ & $100.0 \%(431)$ & $100.0 \%(406)$ & $100.0 \%(2300)$ \\
\hline \multicolumn{6}{|l|}{ Age } \\
\hline Age 10-14 & $5.6 \%(47)$ & $2.5 \%(42)$ & $8.1 \%(35)$ & $7.1 \%(29)$ & $1.2 \%(27)$ \\
\hline Age 15-17 & $29.3 \%(247)$ & $15.7 \%(269)$ & $67.3 \%(290)$ & $66.5 \%(270)$ & $9.2 \%(212)$ \\
\hline Age 18-19 & $3.3 \%(28)$ & $9.6 \%(164)$ & $24.1 \%(104)$ & $25.9 \%(105)$ & $14.6 \%(335)$ \\
\hline Age 20-21 & $1.7 \%(14)$ & $8.1 \%(138)$ & $0.2 \%(1)$ & $0.2 \%(1)$ & $13.8 \%(317)$ \\
\hline Age 22-24 & $6.2 \%(52)$ & $21.1 \%(360)$ & $0.2 \%$ & $0.2 \%$ & $17.9 \%(412)$ \\
\hline Age 25-29 & $8.2 \%(69)$ & $15.1 \%(259)$ & - & - & $11.2 \%(257)$ \\
\hline Age 30-34 & $7.8 \%(66)$ & $16.7 \%(285)$ & - & - & $8.3 \%(192)$ \\
\hline Age 35-44 & $14.9 \%(126)$ & $3.8 \%(65)$ & - & - & $5.6 \%(128)$ \\
\hline Age 45-54 & $12.0 \%(101)$ & $3.1 \%(53)$ & - & - & $4.5 \%(104)$ \\
\hline Age 55-64 & $11.1 \%(94)$ & $2.6 \%(45)$ & - & - & $7.4 \%(171)$ \\
\hline Age 65 and above & - & $1.8 \%(30)$ & - & - & $6.3 \%(145)$ \\
\hline Total & $100.0 \%(844)$ & $100.0 \%(1710)$ & $100.0 \%(431)$ & $100.0 \%(406)$ & $100.0 \%(2300)$ \\
\hline \multicolumn{6}{|l|}{ District } \\
\hline Center & $25.8 \%(218)$ & $27.3 \%(466)$ & $31.1 \%(134)$ & $30.3 \%(123)$ & $28.8 \%(663)$ \\
\hline Haifa & $10.9 \%(92)$ & $11.3 \%(194)$ & $11.1 \%(48)$ & $10.6 \%(43)$ & $10.3 \%(237)$ \\
\hline Jerusalem & $12.8 \%(108)$ & $12.1 \%(207)$ & $8.4 \%(36)$ & $9.1 \%(37)$ & $13.6 \%(312)$ \\
\hline Judea and Samaria & $8.9 \%(75)$ & $10.1 \%(172)$ & $7.4 \%(32)$ & $6.7 \%(27)$ & $6.7 \%(153)$ \\
\hline North & $9.2 \%(78)$ & $7.5 \%(128)$ & $8.1 \%(35)$ & $10.3 \%(42)$ & $8.7 \%(201)$ \\
\hline South & $13.5 \%(114)$ & $14.2 \%(242)$ & $15.8 \%(68)$ & $14.8 \%(60)$ & $12.0 \%(276)$ \\
\hline Tel-Aviv & $17.9 \%(151)$ & $16.6 \%(284)$ & $16.5 \%(71)$ & $16.3 \%(66)$ & $19.9 \%(458)$ \\
\hline Unknown & $0.9 \%(8)$ & $1.0 \%(17)$ & $1.6 \%(7)$ & $2.0 \%(8)$ & - \\
\hline total & $100.0 \%(844)$ & $100.0 \%(1710)$ & $100.0 \%(431)$ & $100.0 \%(406)$ & $100.0 \%(2300)$ \\
\hline \multicolumn{6}{|l|}{ Religious identity } \\
\hline Religious & $21.6 \%(182)$ & $22.5 \%(384)$ & $25.3 \%(109)$ & $21.4 \%(87)$ & $17.1 \%(393)$ \\
\hline Secular & $39.5 \%(333)$ & $37.4 \%(639)$ & $46.4 \%(200)$ & $48.3 \%(196)$ & $50.1 \%(1152)$ \\
\hline Traditional & $24.4 \%(206)$ & $27.2 \%(465)$ & $22.0 \%(95)$ & $24.1 \%(98)$ & $20.0 \%(460)$ \\
\hline Ultra-orthodox & $14.6 \%(123)$ & $12.9 \%(221)$ & $6.0 \%(26)$ & $6.2 \%(25)$ & $12.8 \%(295)$ \\
\hline Unknown & - & $0.1 \%(1)$ & $0.2 \%(1)$ & - & - \\
\hline Total & $100.0 \%(844)$ & $100.0 \%(1710)$ & $100.0 \%(431)$ & $100.0 \%(406)$ & $100.0 \%(2300)$ \\
\hline
\end{tabular}

\subsection{Measures}

Since smoking is generally disapproved of by society, there is a concern about a social desirability bias among adults and youth (Moskowitz, 2004). To avoid this bias, several techniques were employed, such as thoughtful sequencing retrieval for factual questions, avoiding numeric questions about the intensity of smoking (cf. Tourangeau, Rips, \& Rasinski, 2000), and the use of language compatible with the terminology used by nicotine users.

The basic classification of each subject was his/her experience with and use of nicotine products. The participants were asked if and for how long they have used nicotine products, whether cigarettes, hookah, IQOS, or e-cigarettes. According to the subjects' responses to this question, they were sorted in a way that affected the type of questions each subject was requested to answer. Never-smoked youths were required to answer only questions about their knowledge and opinion of nicotine products, while never-smoked adults were filtered out of the surveys in March-April 2018 and 2019 since the importance of their participation was less relevant to the objectives of these two surveys.

The product types options presented to participants who have tried (triers), used (former users), or use (active users) nicotine products today were packaged cigarettes, roll-your-own tobacco, hookah, cigars, and cigarillos, electronic cigarettes, and IQOS. Although JUUL is a brand of electronic cigarettes, the brand was presented as a separate type of product, to avoid misunderstanding by participants who use JUUL but see it as a different type of nicotine product (Note 10).

In the survey of March-April 2019, the active users and some of the triers were asked about the main reason that led them to try electronic cigarettes as a preliminary exploration of the subject. 


\subsection{Measurement Model}

In addition to descriptive statistics, the researchers used an accelerated registration on aggregated results for examining the correlation between triers and users of a product.

In 1998, the World Health Organization (WHO) published a standard classification of smoking habits and intensity density, for the benefit of comparing smoking rates between countries (World Health Organization, 1998). Up until then, researchers used many different and inconsistent methods of measurement (Dent, Sussman, Johnson, Hansen, \& Flay, 1987; Marcus, Giovino, Pierce, \& Harel, 1993; Nafstad et al., 1996).

The WHO classification set the use of a base of 100 cigarettes since birth as a benchmark for defining a smoker (World Health Organization, 1998). Those who tried fewer than 100 cigarettes but were non-daily users were defined as non-smokers, which eliminated the distinction between triers and never-smokers. This categorization is methodologically problematic for several reasons:

- Categories measuring the numeric intensity of a behaviour increase the social desirability bias (Tourangeau et al., 2000);

- $\quad$ This limits the ability to measure addiction rates (DiFranza et al., 2000);

- $\quad$ and it limits the ability to estimate the distribution of nicotine products (ibid.).

The WHO also suggested classifying adolescents differently from adults, by defining any youth who smoked even once in the last month as a daily user (World Health Organization, 1998). However, inconsistent measuring makes it impossible to analyze the adoption of the product over a lifespan, from embracing the habit at an early age until cessation or death.

Although the WHO guidelines do not require it, the United States Centers for Disease Control and Prevention (CDC) defines the intensity of use according to the number of days and the average number of cigarettes per day the subject smoked in the last 30 days (Centers for Disease Control and Prevention (CDC), 2019). Such detailed information is difficult for a person to remember, let alone going back over a long period such as 30 days. The survey further limits its age range to 18 -year-olds and above, although the habit of using nicotine products may start at a younger age.

The research limitations caused by the 100 cigarettes benchmark were also noted by Wasim Maziak, Kenneth Ward, Rima Afifi, and Thomas Eissenberg (Maziak, Ward, Afifi Soweid, \& Eissenberg, 2005) with regards to their field research on Hookah use in Syria (Maziak, Fouad, et al., 2004; Maziak, Rastam, et al., 2004; Maziak, Ward, \& Eissenberg, 2004; Rastam, Ward, Eissenberg, \& Maziak, 2004; Ward et al., 2005). The group resolved this obstacle by creating a classification of five categories: "Never," "Smoked in the past", "Monthly", "Weekly" and "Daily" (Maziak et al., 2005).

In the early survey of March-April 2018 of this research, some of our respondents replied that they only tried smoking a few times and abandoned the habit. In the following surveys, we added the additional rubric of "tried few times." The addition of this further option of "tried a few times" affected the categories of both "never users" and "former users." The per cent. of "former users" decreased substantially, revealing the highly addictive influence of nicotine, and the low odds of cessation. Finally, we formulated the following scale (illus. Figure 7), which resembles the Maziak, Ward, Afifi, and Eissenberg classification system:

- Daily users: Respondents who use a nicotine product every day or almost every day. This category applies mainly to users of casual types, such as combustible cigarettes, RYO cigarettes, IQOS, and electronic cigarettes (Note 11).

- Weekly users: Respondents who use a nicotine product once or twice a week. This category is appropriate for users who prefer a leisure type of nicotine products, such as hookah, cigar, or pipe, and its intensity of use is more apt than a definition as daily users. This category is also suitable for cigarette users who smoke on social occasions, or during the weekend.

- Occasional users: Respondents who use a nicotine product once in a while, at an intensity lower than once a week.

- Former users: Respondents who smoked in the past (for at least two consecutive months) and quit smoking.

- Few times triers: Respondents who tried smoking a nicotine product a few times in their lives.

- Never users: Responders who never tried a nicotine product, even once. 


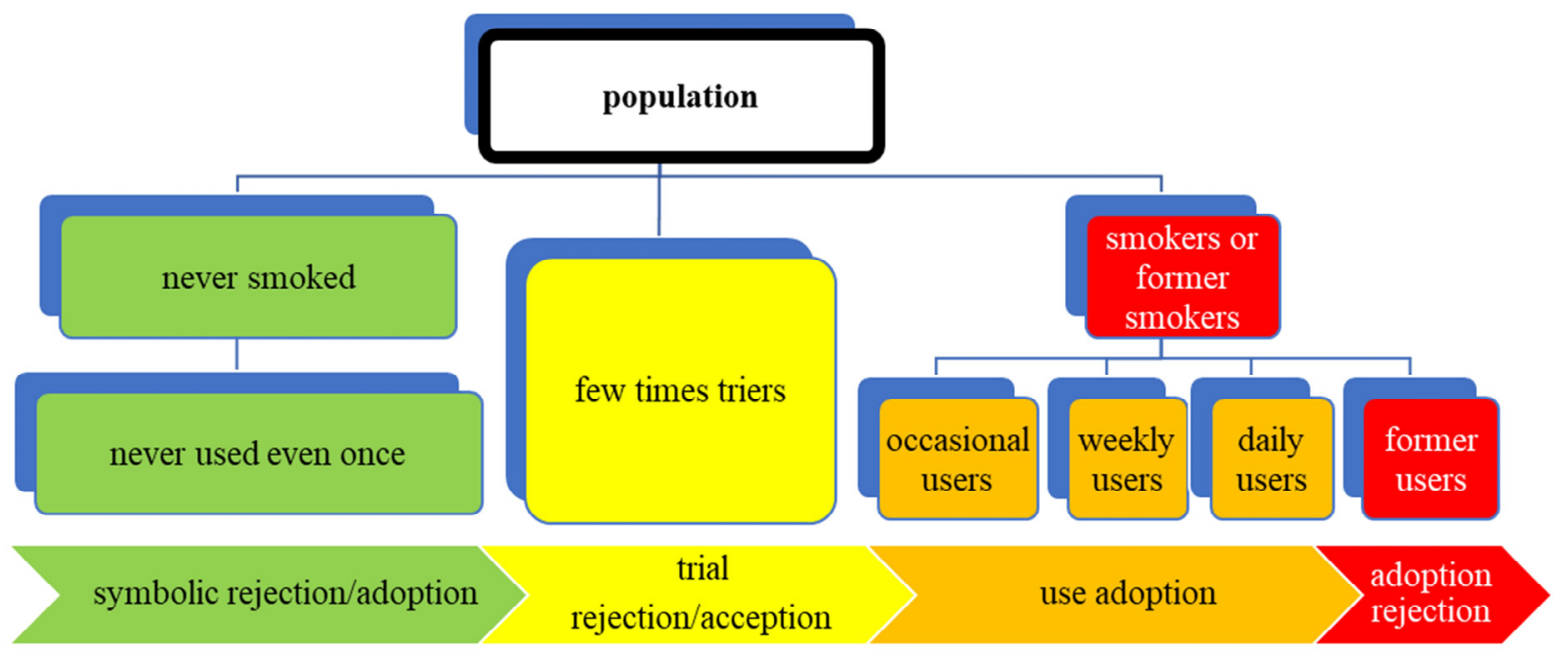

Figure 7. Comparison between a generic consumption flowchart and the intensity of nicotine products use Note. Based on Klonglan and Coward, 1970.

It is accepted to classify the period of life between childhood and adulthood into four stages: early adolescence (ages 10-13); middle adolescence (ages 14-17); late adolescence (ages 18-21); and emerging adulthood (ages 18-25). Besides specific differences in physical, emotional, and cognitive development, these age groups are shaped by social factors such as legal status and participation in the institutions of society (Steinberg, 2017). For example, the military or civilian conscription of most Israeli youngsters at the ages of 18-21 (Note 12) influences the range of ages for each adolescence stage. To correlate the adolescence process in Israel with the conventional model, in this study, we defined the stages as follow:

- $\quad$ Early adolescence: the age-range of lower secondary (middle school) education, ages 12-14;

- Middle adolescence: the age-range of upper secondary (high school) education, ages 15-17;

- Late adolescence: the age-range of military or civilian service, ages 18-21;

- $\quad$ Emerging adulthood: the main age-range of undergraduate education, ages 22-24.

\section{Results}

Subgrouping the sample by the above age groups revealed that the Israeli population develops the habit of nicotine use gradually, beginning in early adolescence up until the age of 35 . Beyond 35, the proportion of users remains stable.

\subsection{The Importance of Triers as an Index}

The primary increase in the use of nicotine products occurs from early youth to the age of 35 . Beyond the age of 35 , the rate of cessation increases as people get older (illus. Figure 8). 


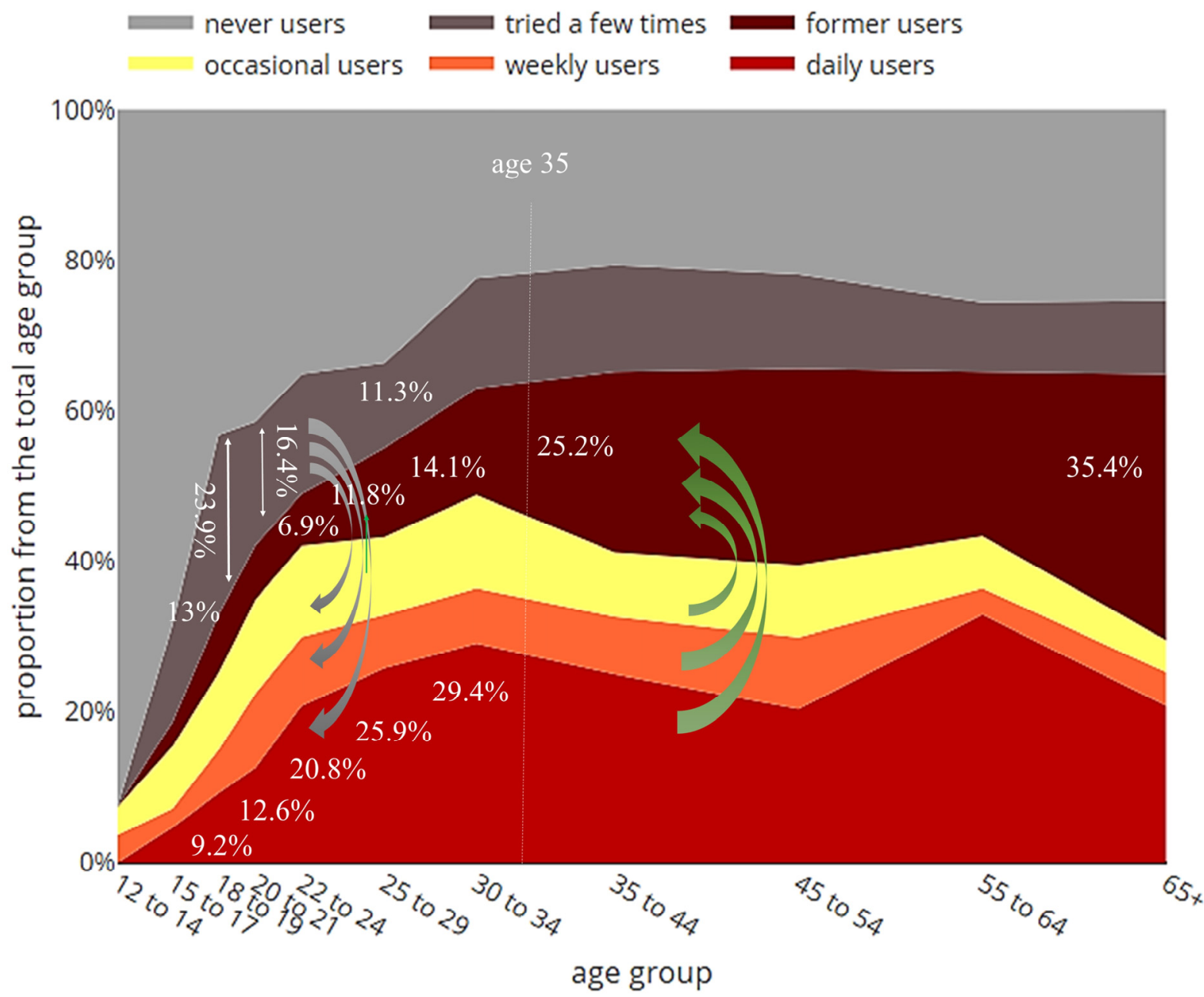

Figure 8. Nicotine use habits in the population, by age groups (Wave of April 2019)

Although the age range between 12 and 35 is only a quarter of a human's life expectancy, this group of people is the most interesting to study, since these are the years when users adopt the nicotine products habit.

Shortly after passing the minimum legal age for purchasing nicotine products (age 18), the rate of triers almost doubles in size: reaching the rate of $23.9 \%(95 \% \mathrm{CI}[19.34,28.46])$ after the shift from the $15-17$ age-group to the 18-19 age-group. Among the 20-21 age-group, some of these triers have become regular users, as revealed by a growth of $9.6 \%$ in active smokers, which is a lot more than the decrease in the rate of triers (Figure 9). Most of the movement at ages above 19 is towards becoming daily users, which negatively affects the number of non-smokers, triers, and even former smokers, especially among the age-group of 22-24 (Figure 9). 


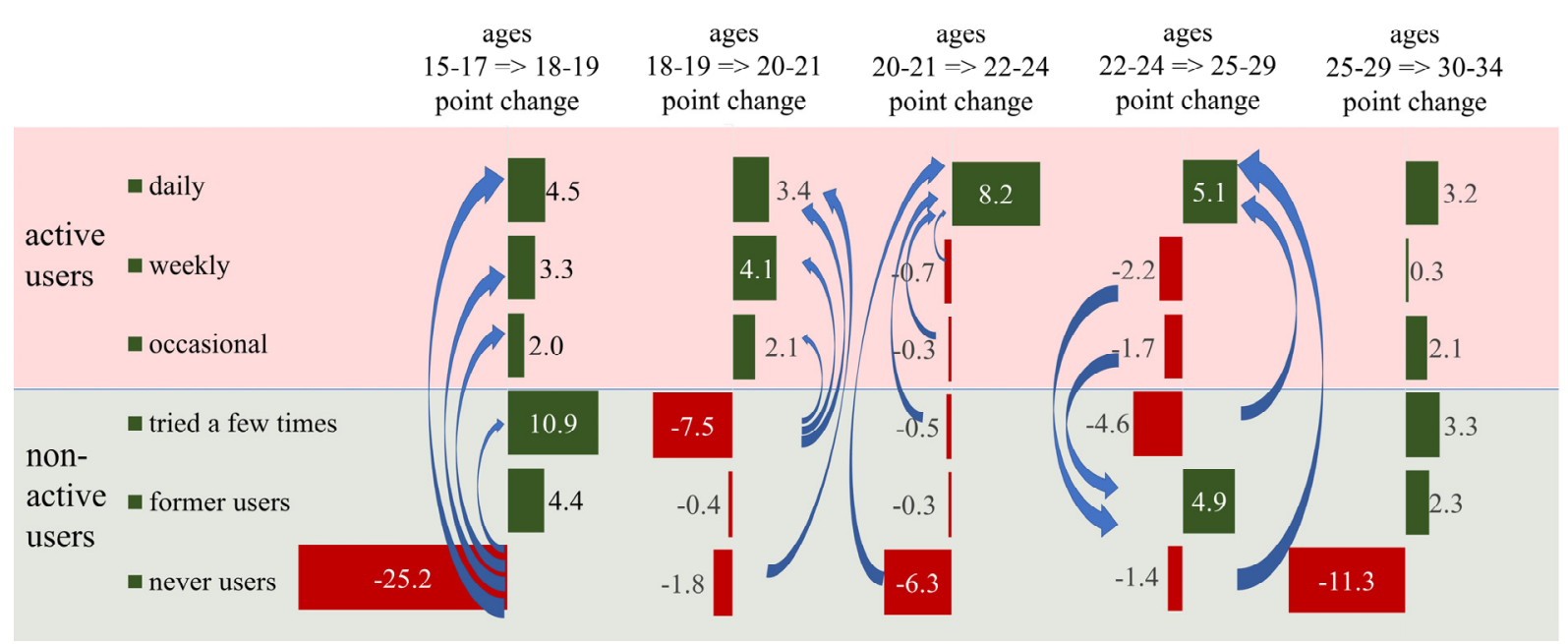

Figure 9. Point change between age groups by duration (Wave of April 2019)

Cessation starts to increase among the 25-29 age-group, while the weight of triers returns to the level it was among the middle adolescence group (age-group 15-17), before peaking among 18 years old young-adults and above. The effects of the termination of the sales ban at the age of 18 finally come to an end, along with other reasons (Note 13). Starting at the age of 25, the dynamics of the market transform from mostly adoption by new users to rejection by adopted users.

\subsection{Smoking vs. Vaping: The Subjectivity of Users as Non-smokers}

It was clear from the results of the last wave, conducted in April 2019, that respondents who mainly use electronic cigarettes differentiate between "smoking" and "vaping." This is expected, as previous research has shown that both legal interests (Willis, Haught, \& Morris, 2017) (Note 14) and self-image encourage electronic cigarettes users to see themselves not as smokers, but as vapers (Agaku, Odani, Vardavas, \& Neff, 2018; Young-Wolff et al., 2017). An estimated $12.6 \%$ of triers $(95 \%$ CI $[9.48,15.7])$ and $12.9 \%$ of active users (95\% CI $[9.08,16.55]$ ) of either THP (tobacco heating products) or ENDS products replied as if "vaping" is not "smoking" (Note 15).

Table 3. An estimated portion of nicotine product users who define their vaping behaviour as different from "smoking"

\begin{tabular}{lllll}
\hline & $\hat{P}(f)$ & $P(f)$ & MOE Adj. & $95 \%$ CI Adj. \\
\hline ever used THP and ENDS & $66(12.6 \%)$ & $36(12.6 \%)$ & $3.11 \%$ & {$[9.48,15.7]$} \\
active users of THS and ENDS & $41(12.9 \%)$ & $25(12.8 \%)$ & $3.74 \%$ & {$[9.08,16.55]$} \\
\hline
\end{tabular}

\subsection{The Consumer Experience of Each Type of Nicotine Product}

Geography and culture influence the orientation to certain types of nicotine products. The predominance of packed cigarettes is reflected in the findings of the current research. Figure 10(a) shows very clearly that almost all of the triers, users, and former users of nicotine products above the age of 35 have had some experience with packed cigarettes. Younger participants tried packed cigarettes widely, but some limit themselves to the inexpensive alternative of roll-your-own products (Note 16). The difference is evident mainly at ages below 30 (see the comparison between Figure 10(a) and Figure 10(c)).

The prevalence of triers, users, and former users of hookahs is second only to combustible cigarettes. This result is expected since previous research arrived at similar results in Israel (Baron-Epel, Shalata, \& Hovell, 2015) and other eastern Mediterranean countries (Maziak et al., 2015; Tucktuck, Ghandour, \& Abu-Rmeileh, 2017) (Note 17). The rate found in the young adult age-group (ages 25 to 35) in the current research indicates a strong attraction to this product type, reaching about half of the population (Figure 10(d)). Nonetheless, the popularity of the hookah as a product type among potential consumers seems to be limited to a certain age of about 35 , beyond which potential consumers are less attracted (Figure 10(d)). 

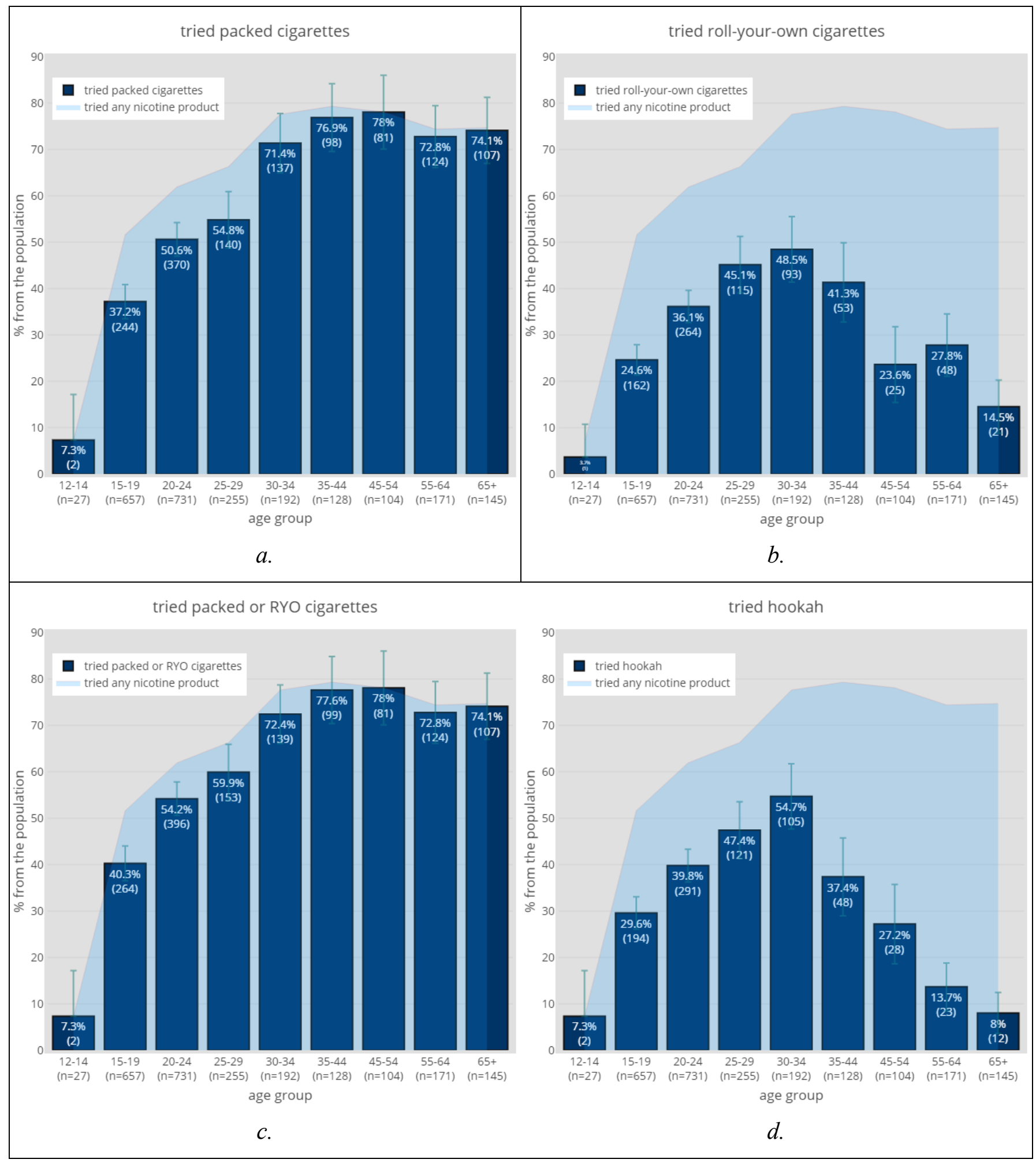


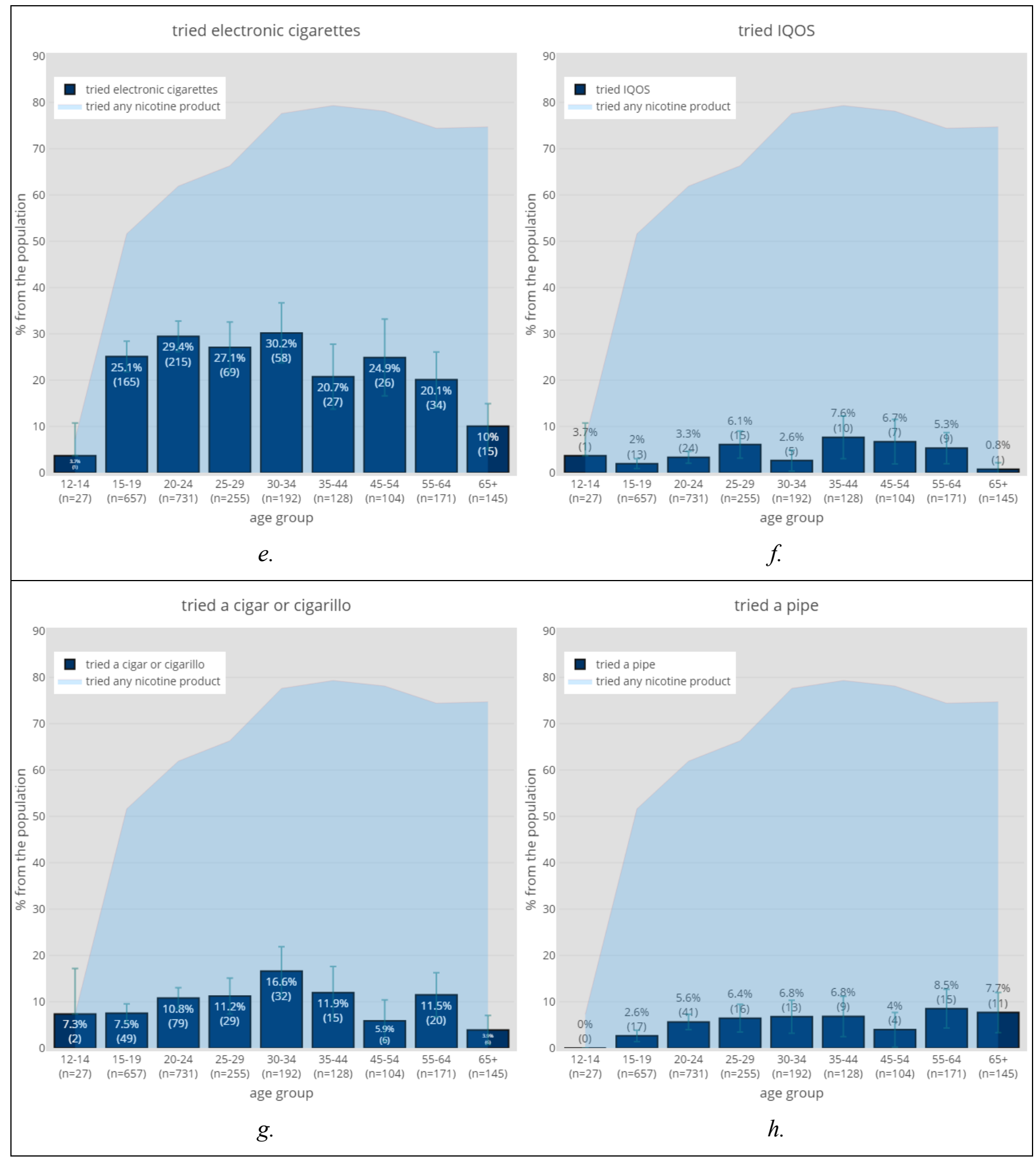

Figure 10. The proportion of triers of nicotine products, by product $(n=2296)$

Unlike hookah, the age distribution among electronic cigarette triers, users, and former users is balanced between the age-groups (Figure 10(e)).

The pipe, cigar, and cigarillo are related by their consumption experience to the hookah (Hammal, Mock, Ward, Eissenberg, \& Maziak, 2008), as a product for use as a leisure activity, while the smoking of cigarettes is done both at work and during leisure time (Brandt, 2007). Nonetheless, the different rates of popularity of the hookah 
and other leisure product types (e.g., pipe, cigars, or cigarillos) is basically cultural.

\subsection{Prevalence of Consumers of Each Type of Nicotine Product}

As mentioned above, innovativeness is measured by the inclination to adopt a given product. Therefore, in addition to measuring the prevalence of each product through the experience of at least trying it, each subject was also asked about his/her usage in the last month, by the same categories of product types. Use over the previous month provides a good indication that the product type was adopted and not just tried, especially among respondents above the age of 22 , when most of the population who wished to do so, have already tried a nicotine product $(88.25 \%, 95 \%$ CI $[85.09,91.41])$. We also preferred to limit the age to 24 , to avoid the effects of the growing scale of former users from age 25 onward, as former users are subjects who rejected the category after its adoption.

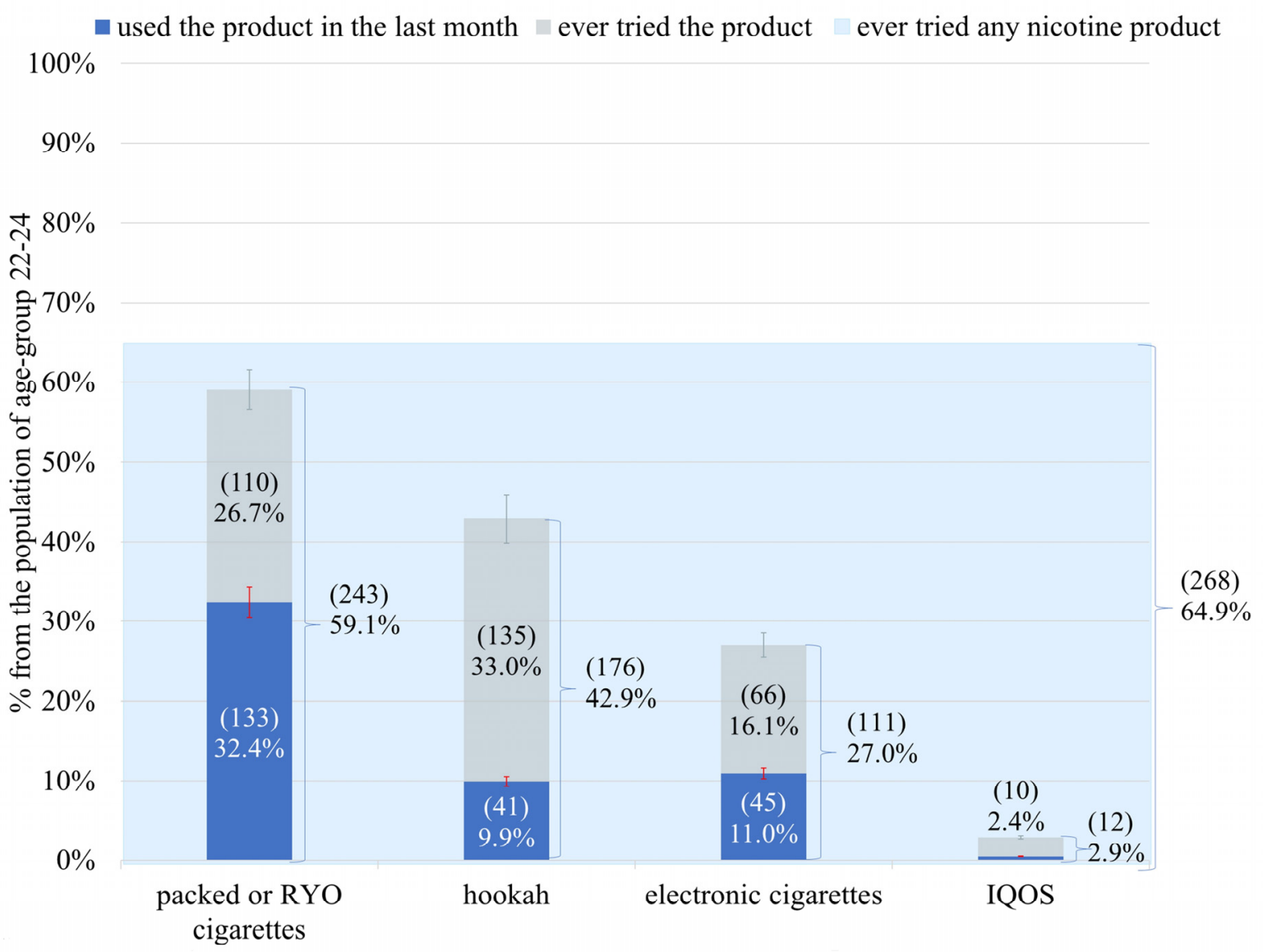

Figure 11. Rate of use in the last month among those who ever tried a certain nicotine product type, by product types (Ages 22-24, Wave March-April 2019)

About half of the combustible cigarette triers eventually adopt this type of product (55.84\%, $95 \%$ CI [49.35, $62.33]$ ), while the prevalence is lower for other types, reaching $40.5 \%$ (95\% CI $[31.41,49.67])$ for electronic cigarettes (illus. Figure 11) (Note 18).

\subsection{The Reasons for Trying Electronic Cigarettes}

In the March-April 2019 wave, the two leading reasons cited by subjects who either had tried, used, or were former users of electronic cigarettes were social influence and cessation. The role played by social influence was significantly different among responders younger than 35 in comparison to those aged 35 and above (cf. Table 4). While social influence serves as the predominant incentive among the group younger than 35 , reaching a rate of $52.2 \%$ (95\% CI $[45.07,59.39])$, at the age of 35 and above, social influence reaches a rate of $29 \%$ (95\% CI $[22.19,35.8])$, which is slightly above the second most influential incentive for cessation in that same age group $(26.04 \%, 95 \%$ CI $[19.46,32.62])$. 
Table 4. The main reason for trying electronic cigarettes among triers and adopters of electronic cigarettes $(\mathrm{n}=$ 466, Wave April 2019)

\begin{tabular}{|c|c|c|c|c|c|c|c|c|}
\hline & \multicolumn{4}{|c|}{ Ages $15-34(n=382)$} & \multicolumn{4}{|c|}{ Ages 35-64 $(n=69)$} \\
\hline & $\hat{p}(f)$ & $P(f)$ & MOE Adj. & 95\% CI Adj. & $\hat{p}(f)$ & $P(f)$ & MOE Adj. & 95\% CI Adj. \\
\hline friend or relative & $210(55 \%)$ & $98(52.2 \%)$ & $7.16 \%$ & {$[45.07,59.39]$} & $20(29 \%)$ & $50(29 \%)$ & $6.81 \%$ & {$[22.19,35.8]$} \\
\hline to quit smoking & $43(11.3 \%)$ & $26(13.8 \%)$ & $4.95 \%$ & {$[8.88,18.78]$} & $18(26.1 \%)$ & $44(26 \%)$ & $6.58 \%$ & {$[19.46,32.62]$} \\
\hline they are healthier & $33(8.6 \%)$ & $14(7.6 \%)$ & $3.80 \%$ & {$[3.8,11.4]$} & $10(14.5 \%)$ & $24(14.2 \%)$ & $5.24 \%$ & {$[8.98,19.46]$} \\
\hline cost less & $19(5 \%)$ & $12(6.4 \%)$ & $3.51 \%$ & {$[2.88,9.9]$} & $7(10.1 \%)$ & $20(11.7 \%)$ & $4.83 \%$ & {$[6.9,16.55]$} \\
\hline more places to use & $18(4.7 \%)$ & $12(6.2 \%)$ & $3.45 \%$ & {$[2.71,9.6]$} & $6(8.7 \%)$ & $13(7.8 \%)$ & $4.01 \%$ & {$[3.74,11.77]$} \\
\hline Flavors & $17(4.5 \%)$ & $7(3.9 \%)$ & $2.76 \%$ & {$[1.1,6.62]$} & $1(1.4 \%)$ & $2(1.2 \%)$ & $1.63 \%$ & {$[0,2.83]$} \\
\hline $\begin{array}{l}\text { I see them } \\
\text { everywhere }\end{array}$ & $14(3.7 \%)$ & $7(3.6 \%)$ & $2.65 \%$ & {$[0.9,6.21]$} & $2(2.9 \%)$ & $5(3 \%)$ & $2.54 \%$ & {$[0.41,5.49]$} \\
\hline easier to get & $9(2.4 \%)$ & $4(2.2 \%)$ & $2.12 \%$ & {$[0.12,4.37]$} & $3(4.3 \%)$ & $7(4.2 \%)$ & $2.99 \%$ & {$[1.16,7.15]$} \\
\hline for fun & $3(0.8 \%)$ & $1(0.4 \%)$ & $0.93 \%$ & {$[0,1.35]$} & $0(0 \%)$ & $0(0 \%)$ & $0 \%$ & {$[0,0]$} \\
\hline $\begin{array}{l}\text { famous people use } \\
\text { them }\end{array}$ & $3(0.8 \%)$ & $1(0.4 \%)$ & $0.93 \%$ & {$[0,1.35]$} & $0(0 \%)$ & $0(0 \%)$ & $0 \%$ & {$[0,0]$} \\
\hline less smelly & $2(0.5 \%)$ & $1(0.8 \%)$ & $1.24 \%$ & {$[0,1.99]$} & $0(0 \%)$ & $0(0 \%)$ & $0 \%$ & {$[0,0]$} \\
\hline other & $11(2.9 \%)$ & $5(2.5 \%)$ & $2.25 \%$ & {$[0.28,4.78]$} & $2(2.9 \%)$ & $5(3 \%)$ & $2.54 \%$ & {$[0.41,5.49]$} \\
\hline
\end{tabular}

Health $(7.6 \%, 95 \% \mathrm{CI}[3.8,11.4])$ and marketing instruments such as cost $(6.39 \%, 95 \%$ CI $[2.88,9.9])$, flavors $(3.86 \%, 95 \%$ CI $[1.1,6.62])$, distribution $(2.25 \%, 95 \%$ CI $[0.12,4.37])$ or better smell $(0.75 \%, 95 \%$ CI $[0,1.99])$ were insignificant incentives for all ages.

\section{Discussion}

Following Johnson and Jones' model of classification of new products by product objectives (Johnson \& Jones, 1957), it is apparent that the intention of the manufacturers and vendors of electronic cigarettes was to develop a new market alongside the current one for the same need, by framing the electronic cigarettes as a really-new product. Manufacturers and vendors of electronic cigarettes differentiate their products from other types of nicotine products by defining their motor-habit-system differently, as "vaping" and not "smoking" (Eversman, 2015; Laestadius, Wahl, \& Cho, 2016; Shen, Banerjee, Greene, Carpenter, \& Ostroff, 2017; Willis et al., 2017; Young-Wolff et al., 2017). This strategy is executed to enlarge the variety of product types on the market, while at the same time hoping to enlarge the number of consumers consuming nicotine products (cf. Crawford, 1972; Johnson \& Jones, 1957; Wasson, 1974).

The rate of adoption found among triers of electronic cigarettes resembles the results of Ryan and Gross (Ryan \& Gross, 1950), who also found a reverse correlation between prevalence and trial period. Although electronic cigarettes have a better comfort design than filter cigarettes, the rate of adoption by triers of electronic cigarettes is lower than the rate of adoption among triers of filter cigarettes. These findings support the assumption by Midgley and Dowling (1978), that prevalence affects the rate of adoption more than the product comfort design or other advantages. Consequently, it is expected that the rate of adoption among triers will rise, as the adoption rates of electronic cigarettes becomes more widespread in the population (cf. Ryan \& Gross, 1950). Contrary to the assumption that most triers succeed in adopting the product (Wasson, 1974), the current research shows a high rate of rejection per product. Indeed, the failure rate is higher than the success rate for each nicotine product type, excluding combustible cigarettes $(55.84 \%, 95 \%$ CI [49.35, 62.33]).

\subsection{Diffusion of Innovation}

The significant rate of rejection by triers of each product also emphasizes the need to distinguish between the stages of symbolic adoption, trial period, and use adoption of the product. The diffusion of an innovation seems to be an outcome of an increase in the triers and the adopters who switch from one product type to another in some correlated proportion. The increase in triers comes from the symbolic adopters, and the increase in use adopters comes from the triers who completed the learning process.

In accordance with the model offered by Rogers (2003), while the rate of triers of filter cigarettes among the 22-24 age-group reaches the late majority $(59.07 \%, 95 \%$ CI [54.32, 63.82]), the rate of actual adopters among the same population is limited only to the early majority $(32.39 \%, 95 \%$ CI $[27.87,36.91])$. Although the rate of actual adopters is the rate of the early majority, the next individual who tries the product for the first time will come from the late majority population, since the rate of triers is at the level of the late majority.

As for the electronic cigarette product type, the rate of triers among the 22-24 age-group is at the level of the 
early majority $(27.03 \%, 95 \%$ CI $[22.74,31.32])$. Therefore, the next individual who tries the product for the first time will belong to the early majority population, although the rate of actual adopters for the same population is limited only to the early adopters $(10.98 \%, 95 \%$ CI $[7.95,14])$.

The rate of adopters among triers of certain products correlates to the rate of triers in the general population (cf. Ryan \& Gross, 1950). An exponential regression was calculated to predict the adoption probability, based on trial and use rates for the 20-21 and 22-24 age-groups, for combustible cigarettes, THP (IQOS), and ENDS (illus. Figure 12).

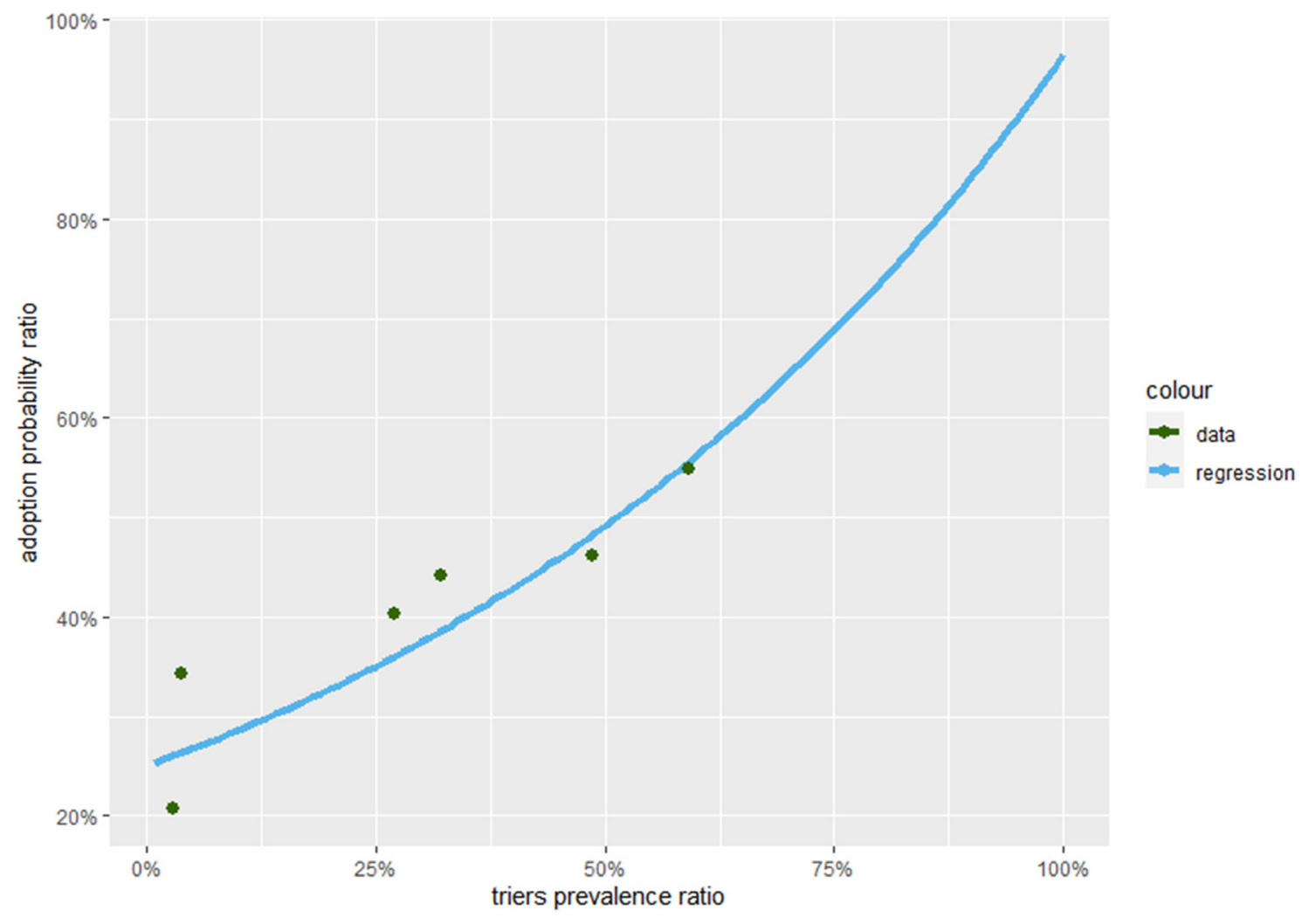

Figure 12. Correlation between adoption probability and the prevalence of triers

The prevalence of triers was a significant predictor of adoption probability (Note 19). From these variables, the following formula was derived to predict the prevalence of users:

$$
\widehat{\mathrm{ADR}}=\frac{\overline{U S E}}{\overline{T R Y}} \Leftrightarrow \overline{\mathrm{ADR}}=0.25 \cdot \operatorname{EXP}(1.35)=0.25 e^{1.35 x} \quad \therefore \quad \overline{U S E}=\overline{\operatorname{try}} \cdot 0.25 e^{1.35 \cdot \overline{t r y}}
$$

$\mathrm{ADR}=$ Adoption probability

TRY $=$ Triers

$\mathrm{USE}=$ Adopters

Figure 13 presents simply the correlation between triers, adopters, and the adoption probability, by rates of a certain milestone in the diffusion of radical innovation as a really-new product. The model, as illustrated in Figure 13, merges the market dynamics according to Levitt's "product life cycle" model (Levitt, 1965), and social adoption according to Rogers' "diffusion of innovation" model (Rogers, 2003). The exponential growth in the adoption probability out of the prevalence of triers illustrates the stronger impact of social influence over the rational evaluation by the individual. A trial acceptance by an individual depends significantly on the extent of symbolic adoption by other members of his/her society. 


\section{ever tried electronic cigarette used electronic cigarette in the last month}

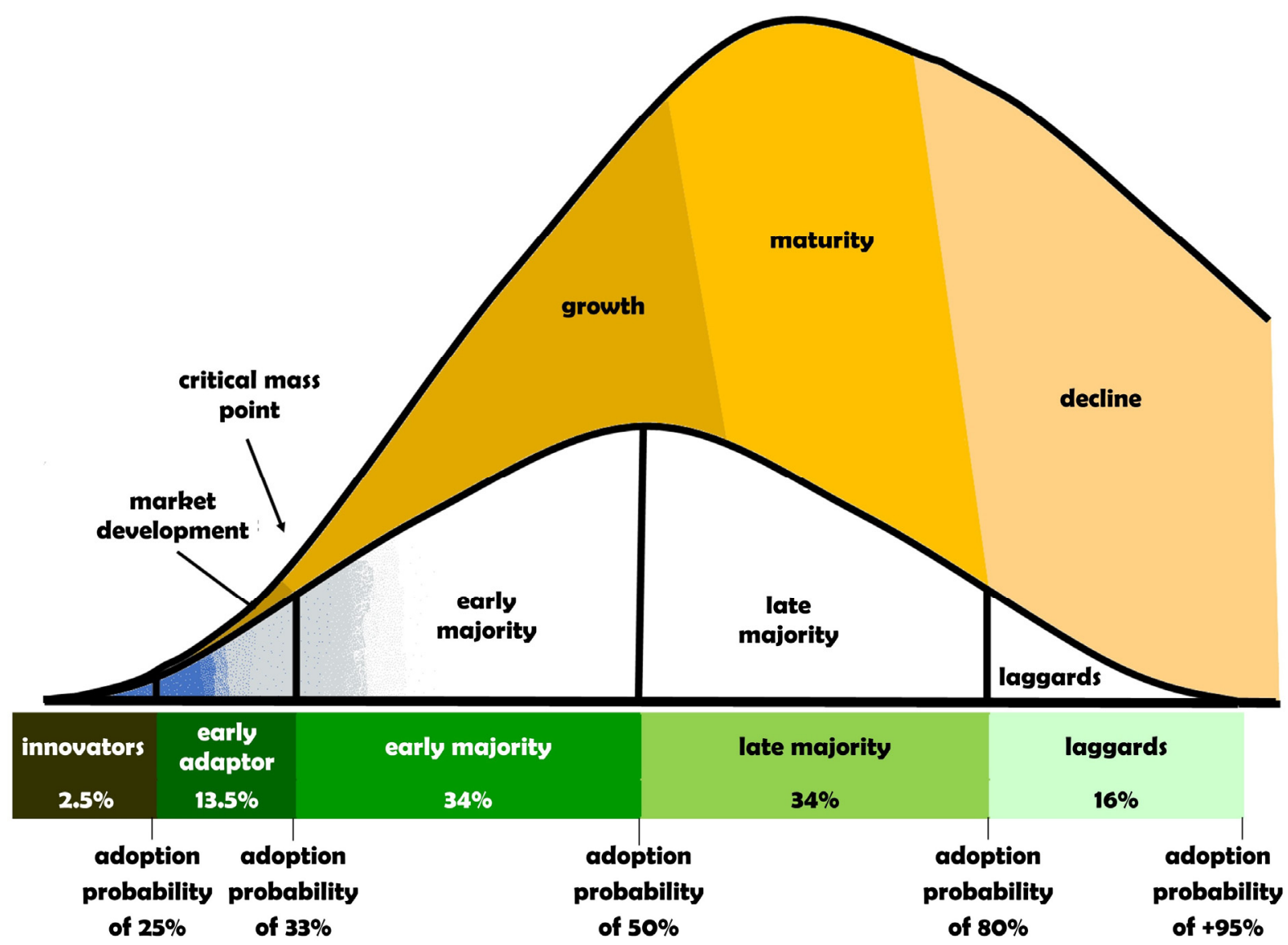

Figure 13. The innovation diffusion model by Rogers (2003) and the model of product life cycle by Levitt (1965), applied to the electronic cigarette product type, April 2019

The understanding that the rate of triers is more significant than the rate of use-adopters also contradicts Rogers' assumption that the early majority will start to try a new product only after the adoption of the product by the early adopters. The early majority also begin their trial experience after the early adopters, even if early adopters rejected the product to some extent during the trial period (illus. Figure 13).

The results of this research data illustrate a market dynamic where there is an entrance of the early majority following the trials of the early adopters, even though part of the early adopters rejects the product. It could be that the rate of success beyond the critical mass point and into the "take-off" period (def. Rogers, 2003, pp. 34, 370-371) depends on the proportion of trial acceptance among the early adopters, but this speculation could not be confirmed by the data of the current research. The strong social influence for trying electronic cigarettes ensures that electronic cigarettes penetrated the early majority population. Unlike the early adopters, who communicate by being advisors, the early majority prefer to garner and share their information from their peer groups of friends or neighbours, as they are more socially dependent than the early adopters (Lionberger, 1954; Lionberger \& Coughenour, 1957; Rogers \& Shoemaker, 1971; Wilkening, 1950). Their final act of purchasing an innovative product depends more on social engagement than for the early adopters (Note 20).

As for IQOS, it seems that the brand, as well as the product type itself, has not passed the market development stage. It has barely reached the early adopters and remains an innovators' product. Since IQOS is not an ENDS product, but a THP product, IQOS is defined as a brand, which represents a separate type of products. Several Supreme Court decisions in 2017 led to regulative differentiation between ENDS products and THP products (Rosen \& Kislev, 2018). 


\subsection{Predicting Further Development of the Market}

It seems that sales of electronic cigarettes affect the sales of filter cigarettes, just as filter cigarettes affected those of non-filter cigarettes (cf. Figure 2). Although filter cigarettes have been in a gradual decline for a long time, they are still the 'warhorses' (def. Barksdale \& Harris, 1982) of Philip Morris International and British-American Tobacco. As sales continue to decline, the companies that have also developed strong electronic cigarette brands will reduce their expenditures on filter cigarettes in favour of more promising types of nicotine products (cf. Barksdale \& Harris, 1982; Enis et al., 1977).

The electronic cigarette, developed to be the star nicotine product alternative to the filter cigarette, has yet to become a cash cow. But JUUL's success as a market leader demonstrated the existence of solid demand for an electronic cigarette of similar design. As can be expected, in the months following the successful introduction of JUUL in 2019, a boom of imitation brands was launched into the Israeli market, in a rush for the hidden gold of this new highly profitable market (cf. Levitt, 1965). "Logic" (Japan Tobacco International), KILO, and Vype ePen 3 (British-American Tobacco) (Linder, 2019) are just a few examples. The visual appearance of JUUL's device became the dominant design for electronic cigarettes, as JUUL's competitors realized that they had to copy its design to remain in the industry (Shapiro, 1986). The dominant design will ultimately define the use-system of this product type from now onward, and thus, the design of the JUUL device will shape the use of electronic cigarettes shortly, regardless of the actual product brand (ibid.).

As an outcome of the progress of the electronic cigarette as a product type beyond the critical mass point, passing the "market development" stage toward the "growth" stage, there is no longer a need to communicate the product's qualities to the public. The intensive debate in the Israeli media about the values and risks involved in consuming electronic cigarettes is expected to fade away from the public sphere. There is no need for this debate from the industry standpoint since the values and risks of using this product have already been determined in the public consciousness. At this point, the growth in sales beyond the critical mass point is expected to be self-sustaining with little promotional input (cf. Rogers, 2003; Wasson, 1974). Influence through social interaction encourages the continuation of the product's diffusion among new users (Rogers, 2003, p. 370). As the product's life cycle proceeds into the advanced phase of growth and onward to the maturity stage, advertisement and agenda-setting in the media lose their influence over the target audience, while the influence of homophilic interaction increases and becomes the predominant communication for persuading additional individuals to try the new product for the first time (Horsky \& Simon, 1983; Rogers, 2003).

\section{Conclusion}

According to current scholarship, a critical mass point occurs when enough individuals have tried a radical innovation of a CPG product, but its rate of adoption is not the indicator for reaching that point. Therefore, for better monitoring of the diffusion of radical innovation, it is important to measure the prevalence of triers of this innovation alongside the prevalence of adopters.

Rational evaluation characterizes a consumer who tends to purchase a pre-critical-mass-point product, while social influence characterizes consumers who tend to purchase the product post-critical-mass-point. The effect of social influence grows as the prevalence of triers in society increases, reaching a predominant parameter for extending the trial experience of the consumer into the full adoption in an exponential impact.

By using the prevalence of triers as an indicator for measuring the entry of a radically new nicotine product into the market, we were able to identify the sustainability of the really-new product at a much earlier phase. Early understanding of the magnitude of the product's hold in the market increases the possibilities of action by policymakers, while the considerations of the consumers are still rational. Thus, policymakers could oppose the new product before social influence reinforces consumers' consideration, by which time it becomes almost impossible to prevent the diffusion of such a product.

\section{Acknowledgement}

The authors would like to thank Ms. Elana Chipman for her critical reading of the manuscript and her remarks, especially for her assistance regarding the phrasing of the definition of demerit goods. The authors would like to thank Mr. Ori Berger for his statistical remarks. The authors contributed equally to this work. The current research was supported by Smoke Free Israel - The National Initiative for Eradicate Smoking (RA 580634947). The authors have no conflicts of interest to declare, and no financial relationships relevant to this article to disclose.

\section{References}

Adams, P. J., \& Livingstone, C. (2015). Addiction surplus: The add-on margin that makes addictive 
consumptions difficult to contain. International Journal of Drug Policy, 26(1), 107-111. https://doi.org/10.1016/j.drugpo.2014.07.018

Agaku, I. T., \& Alpert, H. R. (2016). Trends in annual sales and current use of cigarettes, cigars, roll-your-own tobacco, pipes, and smokeless tobacco among US adults, 2002-2012. Tobacco Control, 25(4), 451-457. https://doi.org/10.1136/tobaccocontrol-2014-052125

Agaku, I. T., Odani, S., Vardavas, C., \& Neff, L. (2018). Self-identified tobacco use and harm perceptions among US youth. Pediatrics, 141(4), e20173523. https://doi.org/10.1542/peds.2017-3523

Aggarwal, P., Cha, T., \& Wilemon, D. (1998). Barriers to the adoption of really-new products and the role of surrogate buyers. Journal of Consumer Marketing, 15(4), 358-371. https://doi.org/10.1108/07363769810226000

Albert, M. A. (1984). Product life cycle in the cigarette market. Winston-Salem NC: R. J. Reynolds Tobacco Company.

Assink, M. (2006). Inhibitors of disruptive innovation capability: A conceptual model. European Journal of Innovation Management, 9(2), 215-233. https://doi.org/10.1108/14601060610663587

Ayers, J. W., Ribisl, K. M., \& Brownstein, J. S. (2011). Tracking the rise in popularity of electronic nicotine delivery systems (electronic cigarettes) using search query surveillance. American Journal of Preventive Medicine, 40(4), 448-453. https://doi.org/10.1016/j.amepre.2010.12.007

Barksdale, H. C., \& Harris, C. E. (1982). Portfolio analysis and the product life cycle. Long Range Planning, 15(6), 74-83. https://doi.org/10.1016/0024-6301(82)90010-3

Baron-Epel, O., Shalata, W., \& Hovell, M. F. (2015). Waterpipe tobacco smoking in three Israeli adult populations. Israel Medical Association Journal, 17(5), 282-287. Retrieved from https://www.ima.org.il/MedicineIMAJ/viewarticle.aspx?aid=3674

Bartels, J., \& Reinders, M. J. (2011). Consumer innovativeness and its correlates: A propositional inventory for future research. Journal of Business Research, 64(6), 601-609. https://doi.org/10.1016/j.jbusres.2010.05.002

Bauer, R. A., \& Wortzel, L. H. (1966). Doctor's choice: The physician and his sources of information about drugs. Journal of Marketing Research, 3(1), 40-47. https://doi.org/10.1177/002224376600300104

Beal, G. M., \& Rogers, E. M. (1958a). The communication process in the purchase of new products: An application of reference group theory. Public Opinion Quarterly, 22(2), 186-187. https://doi.org/10.1093/poq/22.2.186

Beal, G. M., \& Rogers, E. M. (1958b). The scientist as a referent in the communication of new technology. Public Opinion Quarterly, 22(4), 555-563. https://doi.org/10.1086/266828

Bourne, F. (1956). Group influences in marketing and public relations. Ann Arbor MI: The Foundation for Research on Human Behavior. from https://www.psc.isr.umich.edu/dis/infoserv/isrpub/pdf.php?i=12272243977548091144365\&f=Groupinfluen ce_2686_.PDF

Brandt, A. M. (2007). The cigarette century: The rise, fall, and deadly persistence of the product that defined America. New York NY: Basic Books.

Brexendorf, T. O., Bayus, B., \& Keller, K. L. (2015). Understanding the interplay between brand and innovation management: findings and future research directions. Journal of the Academy of Marketing Science, 43(5), 548-557. https://doi.org/10.1007/s11747-015-0445-6

Brown, A. K., Nagelhout, G. E., van den Putte, B., Willemsen, M. C., Mons, U., Guignard, R., \& Thompson, M. E. (2015). Trends and socioeconomic differences in roll-your-own tobacco use: Findings from the ITC Europe surveys. Tobacco Control, 24(Supplement 3), iiil1-iii16. https://doi.org/10.1136/tobaccocontrol-2014-051986

Brown, S. A., Massey, A. P., Montoya-Weiss, M. M., \& Burkman, J. R. (2002). Do I really have to? User acceptance of mandated technology. European Journal of Information Systems, 11(4), 283-295. https://doi.org/10.1057/palgrave.ejis.3000438

Centers for Disease Control and Prevention (CDC). (2019). Detailed outline of topics in the redesigned national health interview survey (NHIS) sample adult questionnaire. Hyattsville MD. Retrieved from 
https://www.cdc.gov/nchs/data/nhis/AdultNHISRedesignTopics201903.pdf

Chatterjee, R. A., \& Eliashberg, J. (1990). The innovation diffusion process in a heterogeneous population: A micromodeling approach. Management Science, 36(9), 1057-1079. https://doi.org/10.1287/mnsc.36.9.1057

Christensen, C. M., \& Rosenbloom, R. S. (1995). Explaining the attacker's advantage: Technological paradigms, organizational dynamics, and the value network. Research Policy, 24(2), 233-257. https://doi.org/10.1016/0048-7333(93)00764-K

Clark, K. B. (1985). The interaction of design hierarchies and market concepts in technological evolution. Research Policy, 14(5), 235-251. https://doi.org/10.1016/0048-7333(85)90007-1

Cohen, W. M., \& Levinthal, D. A. (1990). Absorptive capacity: A new perspective on learning and innovation. Administrative Science Quarterly, 35(1), 128-152. https://doi.org/10.2307/2393553

Cook, S. A. (2006). "Where there's smoke, there's fire": Tobacco use and the construction of the Canadian citizen, 1890-1930. The Social History of Alcohol and Drugs, 21(1), 69-95. https://doi.org/10.1086/SHAD21010069

Crawford, C. M. (1972). Strategies for new product development. Business Horizons, 15(6), 49-58. https://doi.org/10.1016/0007-6813(72)90061-4

Crompton, J. L., \& Hensarling, D. M. (1978). Some suggested implications of the product life cycle for public recreation and park agency managers. Leisure Sciences, 1(3), 295-307. https://doi.org/10.1080/01490407809512890

Dahlin, K. B., \& Behrens, D. M. (2005). When is an invention really radical?: Defining and measuring technological radicalness. Research Policy, 34(5), 717-737. https://doi.org/10.1016/j.respol.2005.03.009

de Kluyver, C. A. (1977). Innovation and industrial product life cycles. California Management Review, 20(1), 21-33. https://doi.org/10.2307/41164735

Dent, C. W., Sussman, S., Johnson, C. A., Hansen, W. B., \& Flay, B. R. (1987). Adolescent smokeless tobacco incidence: Relations with other drugs and psychosocial variables. Preventive Medicine, 16(3), 422-431. https://doi.org/10.1016/0091-7435(87)90041-7

DiFranza, J. R., Rigotti, N. A., McNeill, A. D., Ockene, J. K., Savageau, J. A., St Cyr, D., \& Coleman, M. (2000). Initial symptoms of nicotine dependence in adolescents. Tobacco Control, 9(3), 313-319. https://doi.org/10.1136/tc.9.3.313

Du, R. Y., \& Kamakura, W. A. (2011). Measuring contagion in the diffusion of consumer packaged goods. Journal of Marketing Research, 48(1), 28-47. https://doi.org/10.1509/jmkr.48.1.28

Enis, B. M., La Garce, R., \& Prell, A. E. (1977). Extending the product life cycle. Business Horizons, 20(3), 46-56. https://doi.org/10.1016/0007-6813(77)90070-2

Euromonitor International. (2017). Passport: Tobacco in Israel. London, UK: Euromonitor International.

Eversman, M. H. (2015). Harm reduction in U.S. tobacco control: Constructions in textual news media. International Journal of Drug Policy, 26(6), 575-582. https://doi.org/10.1016/j.drugpo.2015.01.018

Eysenck, H. J. (1998[1947]). Dimensions of personality. New Brunswick NJ \& London UK: Transaction Publishers.

Fatal, V. (2017). Description and Analysis of Taxation on Cigarettes and Rolling Tobacco. Jerusalem, Israel: The Knesset Research and Information Centre. Retrieved from https://m.knesset.gov.il/EN/activity/mmm/me04049.pdf

Fu, M., Martínez-Sánchez, J. M., Clèries, R., Villalbí, J. R., Daynard, R. A., Connolly, G. N., \& Fernández, E. (2014). Opposite trends in the consumption of manufactured and roll-your-own cigarettes in Spain (1991-2020). BMJ Open, 4(12), e006552. https://doi.org/10.1136/bmjopen-2014-006552

Geels, F. W. (2005). Processes and patterns in transitions and system innovations: Refining the co-evolutionary multi-level perspective. Technological Forecasting and Social Change, 72(6 SPEC. ISS.), 681-696. https://doi.org/10.1016/j.techfore.2004.08.014

Giovino, G. A. (2007). The tobacco epidemic in the United States. American Journal of Preventive Medicine, 33(6), S318-S326. https://doi.org/10.1016/j.amepre.2007.09.008

Global Youth Tobacco Survey (GYTS). (2002). Tobacco use among youth: A cross country comparison. Tobacco 
Control, 11(3), 252-270. https://doi.org/10.1136/tc.11.3.252

Goldenberg, J., Han, S., Lehmann, D. R., \& Hong, J. W. (2009). The role of hubs in the adoption process. Journal of Marketing, 73(2), 1-13. https://doi.org/10.1509/jmkg.73.2.1

Goldsmith, R. E., Flynn, L. R., \& Goldsmith, E. B. (2003). Innovative consumers and market mavens. Journal of Marketing Theory and Practice, 11(4), 54-65. https://doi.org/10.1080/10696679.2003.11658508

Grana, R., Benowitz, N., \& Glantz, S. A. (2014). E-cigarettes: A scientific review. Circulation, 129(19), 1972-1986. https://doi.org/10.1161/CIRCULATIONAHA.114.007667

Hajdu, S. I., \& Vadmal, M. S. (2010). The use of tobacco. Annals of Clinical and Laboratory Science, 40(2), 178-181. Retrieved from http://www.ncbi.nlm.nih.gov/pubmed/20421631

Hammal, F., Mock, J., Ward, K. D., Eissenberg, T., \& Maziak, W. (2008). A pleasure among friends: how narghile (waterpipe) smoking differs from cigarette smoking in Syria. Tobacco Control, 17(2), e3. https://doi.org/10.1136/tc.2007.020529

Hammond, D., Reid, J. L., Rynard, V. L., Fong, G. T., Cummings, K. M., McNeill, A., ... White, C. M. (2019). Prevalence of vaping and smoking among adolescents in Canada, England, and the United States: Repeat national cross sectional surveys. The BMJ, 2019(365), 12219. https://doi.org/10.1136/bmj.12219

Hannah, L. (2006). The whig fable of american tobacco, 1895-1913. The Journal of Economic History, 66(01), 42-73. https://doi.org/10.1017/S0022050706000027

Hart, J. F., \& Mather, E. C. (1961). The character of tobacco barns and their role in the tobacco economy of the United States. Annals of the Association of American Geographers, 51(3), 274-293. https://doi.org/10.1111/j.1467-8306.1961.tb00379.x

Hartnett, A. (2004). The politics of the pipe: Clay pipes and tobacco consumption in galway, Ireland. International Journal of Historical Archaeology, 8(2), 133-147. https://doi.org/10.1023/B:IJHA.0000043698.64896.8b

Hiebert, L. D. (1974). Risk, learning, and the adoption of fertilizer responsive seed varieties. American Journal of Agricultural Economics, 56(4), 764-768. https://doi.org/10.2307/1239305

Hill, C. (2004). Le tabac en France: les vrais chiffres. Paris, France: Documentation Française.

Hill, C. (2015). Le tabac en France, mise à jour. Villejuif, France: Institut Gustave Roussy. Retrieved from https://www.gustaveroussy.fr/sites/default/files/le-tabac-en-france-maj-2015.pdf

Horsky, D., \& Simon, L. S. (1983). Advertising and the diffusion of New products. Marketing Science, 2(1), 1-17. https://doi.org/10.1287/mksc.2.1.1

Huang, J., Duan, Z., Kwok, J., Binns, S., Vera, L. E., Kim, Y., ... Emery, S. L. (2019). Vaping versus JUULing: How the extraordinary growth and marketing of JUUL transformed the US retail e-cigarette market. Tobacco Control, 28(2), 146-151. https://doi.org/10.1136/tobaccocontrol-2018-054382

Hurt, H. T., Joseph, K., \& Cook, C. D. (1977). Scales for the measurement of innovativeness. Human Communication Research, 4(1), 58-65. https://doi.org/10.1111/j.1468-2958.1977.tb00597.x

Im, S., Bayus, B. L., \& Mason, C. H. (2003). An empirical study of innate consumer innovativeness, personal characteristics, and new-product adoption behavior. Journal of the Academy of Marketing Science, 31(1), 61-73. https://doi.org/10.1177/0092070302238602

Im, S., Mason, C. H., \& Houston, M. B. (2007). Does innate consumer innovativeness relate to new product/service adoption behavior? The intervening role of social learning via vicarious innovativeness. Journal of the Academy of Marketing Science, 35(1), 63-75. https://doi.org/10.1007/s11747-006-0007-z

Israel Central Bureau of Statistics. (2018). Statistical abstract of Israel 2018 (Rapport No. 69). Jerusalem, Israel: Israel Central Bureau of Statistics. Retrieved from https://www.cbs.gov.il/en/publications/Pages/2018/Statistical-Abstract-of-Israel-2018-No-69.aspx

Israel Ministry of Health. (2018). Minister of health's report on smoking in Israel 2016 (2nd rev. ed.) [in Hebrew]. Jerusalem, Israel: Israel Ministry of Health \& Israel Center for Disease Control (ICDC). Retrieved from https://www.health.gov.il/PublicationsFiles/smoking_2018.pdf

Israel Ministry of Health. (2019). Minister of health's report on smoking in Israel 2018 [in Hebrew]. Jerusalem, Israel: Israel Minister of Health \& Israel Center for Disease Control (ICDC). Retrieved from https://www.health.gov.il/UnitsOffice/ICDC/HealthAndLifestyle/smoking/Pages/MOH_report.aspx 
Johnson, S. C., \& Jones, C. (1957). How to organize for new products. Harvard Business Review, 35(3), 49-62.

Kamakura, W. A., \& Novak, T. P. (1992). Value-system segmentation: Exploring the meaning of LOV. Journal of Consumer Research, 19(1), 119-132. https://doi.org/10.1086/209291

Karande, K., Merchant, A., \& Sivakumar, K. (2011). Erratum to: Relationships among time orientation, consumer innovativeness, and innovative behavior: The moderating role of product characteristics. AMS Review, 1(2), 99-116. https://doi.org/10.1007/s13162-011-0009-y

King, C. W., \& Summers, J. O. (1970). Overlap of opinion leadership across consumer product categories. Journal of Marketing Research, 7(1), 43-50. https://doi.org/10.1177/002224377000700104

Klioutchkine, K. (2009). "I smoke, therefore I think": Tobacco as liberation in Russian nineteenth-century literature and culture. In M. P. Romaniello \& T. Starks (Eds.), Tobacco in Russian History and Culture: From the Seventeenth Century to the Present (pp. 83-101). New York NY \& London UK: Routledge. https://doi.org/10.4324/9780203875735

Klonglan, G. E., \& Coward, E. W. (1970). The concept of symbolic adoption: A suggested interpretation. Rural Sociology, 35(1), 77-83.

Laestadius, L. I., Wahl, M. M., \& Cho, Y. I. (2016). \#Vapelife: An exploratory study of electronic cigarette use and promotion on instagram. Substance Use and Misuse, 51(12), 1669-1673. https://doi.org/10.1080/10826084.2016.1188958

Lancaster, K. J. (1966). A new approach to consumer theory. Journal of Political Economy, 74(2), 132-157. https://doi.org/10.1086/259131

Lancaster, K. J. (1990). The economics of product variety: A survey. Marketing Science, 9(3), 189-206. https://doi.org/10.1287/mksc.9.3.189

Lancaster, K. J. (1991). The 'product variety' case for protection. Journal of International Economics, 31(1-2), 1-26. https://doi.org/10.1016/0022-1996(91)90054-A

Levitt, T. (1965). Exploit the product life cycle. Harvard Business Review, 43(6), 81-94. Retrieved from https://hbr.org/1965/11/exploit-the-product-life-cycle

Linder, R. (2019, 14 September). What Lies behind the explosion of e-cigarettes in explosions? [in Hebrew]. In The Marker (pp. 24-25). Retrieved from https://www.themarker.com/news/health/.premium-1.7836717

Lionberger, H. F. (1954). The relation of informal social groups to the diffusion of farm information in a northeast Missouri farm community. Rural Sociology, 19(3), 233-243.

Lionberger, H. F., \& Coughenour, C. M. (1957). Social structure and diffusion of farm information: Based on study of 4 farm community in northeast Missouri. Research Bulletin, 28(631), 1-107. Retrieved from https://mospace.umsystem.edu/xmlui/bitstream/handle/10355/57934/AESResearchBulletin.pdf?isAllowed= $\mathrm{y} \&$ sequence $=1$

Lopez, A. D., Collishaw, N. E., \& Piha, T. (1994). A descriptive model of the cigarette epidemic in developed countries. Tobacco Control, 3(3), 242-247. https://doi.org/10.1136/tc.3.3.242

Mackay, J., \& Schluger, N. (2015). Global tobacco epidemic. In R. Loddenkemper \& M. Kreuter (Eds.), The Tobacco Epidemic (2nd ed., Vol. 42, pp. 19-26). Basel Switzerland \& Berlin Gremany: Karger. https://doi.org/10.1159/000369320

Mann, S., \& Gairing, M. (2012). Does libertarian paternalism reconcile merit goods theory with Mainstream Economics? Forum for Social Economics, 41(2-3), 206-219. https://doi.org/10.1007/s12143-010-9084-3

Marcus, S. E., Giovino, G. A., Pierce, J. P., \& Harel, Y. (1993). Measuring tobacco use among adolescents. Public Health Reports, 108(SUPPL. 1), 20-24. Retrieved from https://www.ncbi.nlm.nih.gov/pmc/articles/PMC1403304/

Maziak, W., Fouad, F. M., Asfar, T., Hammal, F., Bachir, E. M., Rastam, S., .. Ward, K. D. (2004). Prevalence and characteristics of narghile smoking among university students in Syria. The International Journal of Tuberculosis and Lung Disease, 8(7), 882-889. Retrieved from https://www.ingentaconnect.com/content/iuatld/ijtld/2004/00000008/00000007/art00013

Maziak, W., Rastam, S., Eissenberg, T., Asfar, T., Hammal, F., Bachir, M. E., ... Ward, K. D. (2004). Gender and smoking status-based analysis of views regarding waterpipe and cigarette smoking in Aleppo, Syria. Preventive Medicine, 38(4), 479-484. https://doi.org/10.1016/j.ypmed.2003.11.021 
Maziak, W., Taleb, Z. B., Bahelah, R., Islam, F., Jaber, R., Auf, R., \& Salloum, R. G. (2015). The global epidemiology of waterpipe smoking. Tobacco Control, 24(Suppl 1), i3-i12. https://doi.org/10.1136/tobaccocontrol-2014-051903

Maziak, W., Ward, K. D., Afifi Soweid, R. A., \& Eissenberg, T. (2005). Standardizing questionnaire items for the assessment of waterpipe tobacco use in epidemiological studies. Public Health, 119(5), 400-404. https://doi.org/10.1016/j.puhe.2004.08.002

Maziak, W., Ward, K. D., \& Eissenberg, T. (2004). Factors related to frequency of narghile (waterpipe) use: The first insights on tobacco dependence in narghile users. Drug and Alcohol Dependence, 76(1), 101-106. https://doi.org/10.1016/j.drugalcdep.2004.04.007

Meenaghan, J., \& O'Sullivan, P. (1986). The shape and length of the product life cycle. Irish Marketing Review, 1, 83-102. https://doi.org/10.21427/D78R3D

Menger, C. (1871). Grundsätze der Volkswirtschaftslehre. Wien, Österreichisch-Ungarische Monarchie: Wilhelm Braumüller. Retrieved from https://oll.libertyfund.org/titles/menger-grundsatze-der-volkswirtschaftslehre

Midgley, D. F., \& Dowling, G. R. (1978). Innovativeness: The concept and its measurement. Journal of Consumer Research, 4(4), 229-242. https://doi.org/10.1086/208701

Miller, D. (1987). Material culture and mass consumption. Oxford UK \& New York NY: B. Blackwell.

Mittelstaedt, R. A., Grossbart, S. L., Curtis, W. W., \& DeVere, S. P. (1976). Optimal stimulation level and the adoption decision process. Journal of Consumer Research, 3(2), 84-94. https://doi.org/10.1086/208655

Moreau, C. P., Markman, A. B., \& Lehmann, D. R. (2001). 'What is it?' Categorization flexibility and consumers' responses to really new products. Journal of Consumer Research, 27(4), 489-498. https://doi.org/10.1086/319623

Moskowitz, J. M. (2004). Assessment of cigarette smoking and smoking susceptibility among youth: Telephone computer-assisted self-interviews versus computer-assisted telephone interview. Public Opinion Quarterly, 68(4), 565-587. https://doi.org/10.1093/poq/nfh040

Mowen, J. C. (2000). The 3M model of motivation and personality: Theory and empirical applications to consumer behavior. New York NY: Springer Science+Business Media. https://doi.org/10.1007/978-1-4757-6708-7

Musgrave, R. A. (1959). The theory of public finance: a study in public economy. Bombay, Calcuta \& Madras, India: Tata - McGraw-Hill Book Company.

Nafstad, P., Kongerud, J., Botten, G., Urdal, P., Silsand, T., Pedersen, B. S., \& Jaakkola, J. J. K. (1996). Fetal exposure to tobacco smoke products: A comparison between self-reported maternal smoking and concentrations of cotinine and thiocyanate in cord serum. Acta Obstetricia et Gynecologica Scandinavica, 75(10), 902-907. https://doi.org/10.3109/00016349609055025

Nelson, R. R., \& Winter, S. G. (1982). An evolutionary theory of economic change. Cambridge MA \& London UK: The Belknap Press of Harvard University Press.

Nourrisson, D. (1988). Tabagisme et antitabagisme en France au XIXe siècle. Histoire, économie et société, 7(4), 535-547. https://doi.org/10.3406/hes.1988.2394

Olshavsky, R. W., \& Spreng, R. A. (1996). An exploratory study of the innovation evaluation process. Journal of Product Innovation Management, 13(6), 512-529. https://doi.org/10.1016/S0737-6782(96)00037-9

Ostlund, L. E. (1974). Perceived innovation attributes as predictors of innovativeness. Journal of Consumer Research, 1(2), 23-29. https://doi.org/10.1086/208587

Parasuraman, A. (2000). Technology readiness index (Tri): A multiple-item scale to measure readiness to embrace new technologies. Journal of Service Research, 2(4), $307-320$. https://doi.org/10.1177/109467050024001

Phillips, F. Y. (2016). The circle of innovation. Journal of Innovation Management, 4(3), 12-31. https://doi.org/10.24840/2183-0606_004.003_0004

Polli, R., \& Cook, V. (1969). Validity of the product life cycle. The Journal of Business, 42(4), 385-400. https://doi.org/10.1086/295215

R Core Team. (2020). R: A language and environment for statistical computing. Vienna, Austria: R Foundation for Statistical Computing. Retrieved from https://www.r-project.org/ 
Raju, P. S. (1980). Optimum stimulation level: Its relationship to personality, demographics, and exploratory behavior. Journal of Consumer Research, 7(3), 272-282. https://doi.org/10.1086/208815

Ram, S., \& Jung, H.-S. (1991). 'Forced' adoption of innovations in organizations: Consequences and implications. Journal of Product Innovation Management, 8(2), 117-126. https://doi.org/10.1111/1540-5885.820117

Rastam, S., Ward, K. D., Eissenberg, T., \& Maziak, W. (2004). Estimating the beginning of the waterpipe epidemic in Syria. BMC Public Health, 4, 32. https://doi.org/10.1186/1471-2458-4-32

Rogers, E. M. (1958). Categorizing the adopters of agricultural practices. Rural Sociology, 23(4), 347-354.

Rogers, E. M. (1959). Farmer-businessman communication. In Second Annual Agricultural Marketing Conference on "Business Strategy" (pp. 35-52). Athens OH: Department of Agricultural Economics and Rural Sociology, the Ohio State University.

Rogers, E. M. (2003). Diffusion of innovations (5th ed.). New York NY: Free Press.

Rogers, E. M., \& Beal, G. M. (1958). The importance of personal influence in the adoption of technological changes. Social Forces, 36(4), 329-335. https://doi.org/10.2307/2573971

Rogers, E. M., \& Shoemaker, F. F. (1971). [Diffusion of innovations] Communication of innovations: A cross-cultural approach (2nd ed.). New York NY \& London UK: The Free Press \& Collier Macmillan Publishers.

Romaniello, M. P. (2007). Through the filter of tobacco: The limits of global trade in the early modern world. Comparative Studies in Society and History, 49(4), 914-937. https://doi.org/10.1017/S0010417507000801

Rosen, L. J., \& Kislev, S. (2018). IQOS campaign in Israel. Tobacco Control, 27(Suppl. 1), s78-s81. https://doi.org/10.1136/tobaccocontrol-2018-054619

Ruprecht, W. (2002). Preferences and novelty. In A. McMeekin, K. Green, M. Tomlinson \& V. Walsh (Eds.), Innovation by Demand: an Interdisciplinary Approach to the Study of Demand and Its Role in Innovation (pp. 56-74). Manchester UK \& New York NY: Manchester University Press. https://doi.org/10.7765/9781526137449.00010

Ryan, B. (1948). A study in technological diffusion. Rural Sociology, 13(3), 273-284.

Ryan, B., \& Gross, N. C. (1943). The diffusion of hybrid seed corn in two Iowa communities. Rural Sociology, $8(1), 15-24$.

Ryan, B., \& Gross, N. C. (1950). Acceptance and Diffusion of Hybrid Corn Seed in Two Iowa Communities. Research Bulletin, 29(372), 662-708. Retrieved from http://ezproxy.cul.columbia.edu/login?url=http://search.ebscohost.com/login.aspx?direct=true\&db=ehh\&A $\mathrm{N}=13074695$ \& site $=$ ehost-live\&scope $=$ site

Saviotti, P. P. (2002). Variety, growth and demand. In A. McMeekin, K. Green, M. Tomlinson \& V. Walsh (Eds.), Innovation by Demand: an Interdisciplinary Approach to the Study of Demand and its Role in Innovation (pp. 41-55). Manchester UK \& New York NY: Manchester University Press. https://doi.org/10.7228/manchester/9780719062674.003.0004

Schumpeter, J. A. (2003[1950]). Capitalism, socialism and democracy (5th ed.). London UK \& New York NY: Routledge, George Allen \& Unwin Ltd.

Shapiro, N. (1986). Innovation, new industries and new firms. Eastern Economic Journal, 12(1), $27-43$. Retrieved from https://www.jstor.org/stable/40357381

Shechter, R. (2003). Selling luxury: The rise of the Egyptian cigarette and the transformation of the Egyptian tobacco market, 1850-1914. International Journal of Middle East Studies, 35(1), 51-75. https://doi.org/10.1017/S0020743803000035

Shen, M. J., Banerjee, S. C., Greene, K., Carpenter, A., \& Ostroff, J. S. (2017). A content analysis of unique selling propositions of tobacco print ads. American Journal of Health Behavior, 41(2), 194-203. https://doi.org/10.5993/AJHB.41.2.11

Sinapuelas, I. C. S., Wang, H. M. D., \& Bohlmann, J. D. (2015). The interplay of innovation, brand, and marketing mix variables in line extensions. Journal of the Academy of Marketing Science, 43(5), 558-573. https://doi.org/10.1007/s11747-015-0437-6

Steenkamp, J. B. E. M., \& Gielens, K. (2003). Consumer and market drivers of the trial probability of new 
consumer packaged goods. Journal of Consumer Research, 30(3), 368-384. https://doi.org/10.1086/378615

Steenkamp, J.-B. E. M., ter Hofstede, F., \& Wedel, M. (1999). A cross-national investigation into the individual and national cultural antecedents of consumer innovativeness. Journal of Marketing, 63(2), 55-69. https://doi.org/10.1177/002224299906300204

Steinberg, L. D. (2017). Adolescence (11th ed.). New York NY: Mcgraw-Hill Education.

Taylor, S., \& Todd, P. (1995). Decomposition and crossover effects in the theory of planned behavior: A study of consumer adoption intentions. International Journal of Research in Marketing, 12(2), 137-155. https://doi.org/10.1016/0167-8116(94)00019-K

Thorelli, H. B., \& Burnett, S. C. (1981). The nature of product life cycles for industrial goods businesses. Journal of Marketing, 45(4), 97-108. https://doi.org/10.1177/002224298104500413

Thun, M., Peto, R., Boreham, J., \& Lopez, A. D. (2012). Stages of the cigarette epidemic on entering its second century. Tobacco Control, 21(2), 96-101. https://doi.org/10.1136/tobaccocontrol-2011-050294

Tourangeau, R., Rips, L. J., \& Rasinski, K. (2000). The psychology of survey response. Cambridge, UK: Cambridge University Press. https://doi.org/10.1017/CBO9780511819322

Tucktuck, M., Ghandour, R., \& Abu-Rmeileh, N. M. E. (2017). Waterpipe and cigarette tobacco smoking among Palestinian university students: A cross-sectional study. BMC Public Health, $18,1$. https://doi.org/10.1186/s12889-017-4524-0

Urban, G. L., Weinberg, B. D., \& Hauser, J. R. (1996). Premarket forecasting of really-new products. Journal of Marketing, 60(1), 47-60. https://doi.org/10.1177/002224299606000105

Vardavas, C. I., \& Agaku, I. T. (2015). Electronic cigarettes: the issues behind the moral quandary. In R. Loddenkemper \& M. Kreuter (Eds.), The Tobacco Epidemic (2nd ed., Vol. 42, pp. 258-267). Basel Switzerland \& Berlin Gremany: Karger. https://doi.org/10.1159/000369506

Walker, D., \& Henderson, M. (2010). Smoking and health in London's East End in the first half of the 19th century. Post-Medieval Archaeology, 44(1), 209-222. https://doi.org/10.1179/174581310X12662382629373

Walsh, C. (1987). Individual irrationality and public policy: In search of merit/demerit policies. Journal of Public Policy, 7(2), 103-134. https://doi.org/10.1017/S0143814X00005201

Ward, K. D., Hammal, F., VanderWeg, M. W., Eissenberg, T., Asfar, T., Rastam, S., \& Maziak, W. (2005). Are waterpipe users interested in quitting? Nicotine and Tobacco Research, 7(1), 149-156. https://doi.org/10.1080/14622200412331328402

Warde, A. (2002). Social mechanisms generating demand: A review and manifesto. In A. McMeekin, K. Green, M. Tomlinson \& V. Walsh (Eds.), Innovation by Demand: an Interdisciplinary Approach to the Study of Demand and Its Role in Innovation (pp. 10-22). Manchester UK \& New York NY: Manchester University Press. https://doi.org/10.7228/manchester/9780719062674.003.0002

Wasson, C. R. (1974). Dynamic competitive strategy \& product life cycles. St. Charles Ill: Challenge Books.

Wilkening, E. A. (1950). A socio-psychological approach to the study of acceptance of innovations farming. Rural Sociology, 15(4), 352-364.

Wilkening, E. A. (1951). Social isolation and response of farmers to agricultural programs. American Sociological Review, 16(6), 836-837. https://doi.org/10.2307/2087514

Wilkening, E. A. (1952). Informal leaders and innovators in farm practices. Rural Sociology, 17(3), $272-275$.

Willett, J. G., Bennett, M., Hair, E. C., Xiao, H., Greenberg, M. S., Harvey, E., ... Vallone, D. (2019). Recognition, use and perceptions of JUUL among youth and young adults. Tobacco Control, 28(1), 115-116. https://doi.org/10.1136/tobaccocontrol-2018-054273

Willis, E., Haught, M. J., \& Morris, D. L. (2017). Up in vapor: Exploring the health messages of e-cigarette advertisements. Health Communication, 32(3), 372-380. https://doi.org/10.1080/10410236.2016.1138388

Wood, S. L., \& Swait, J. (2002). Psychological indicators of innovation adoption: cross-classification based on need for cognition and need for change. Journal of Consumer Psychology, 12(1), 1-13. https://doi.org/10.1207/S15327663JCP1201_01

World Health Organization. (1998). Guidelines for controlling and monitoring the tobacco epidemic. Geneva Switzerland: World Health Organization. Retrieved from https://apps.who.int/iris/handle/10665/42049 
Young-Wolff, K. C., Klebaner, D., Folck, B., Carter-Harris, L., Salloum, R. G., Prochaska, J. J., ... Tan, A. S. L. (2017). Do you vape? Leveraging electronic health records to assess clinician documentation of electronic nicotine delivery system use among adolescents and adults. Preventive Medicine, 105, 32-36. https://doi.org/10.1016/j.ypmed.2017.08.009

Zitzewitz, E. W. (2003). Competition and long-run productivity growth in the UK and US tobacco industries, 1879-1939. Journal of Industrial Economics, 51(1), 1-33. https://doi.org/10.1111/1467-6451.00189

\section{Notes}

Note 1. i.e., Demerit goods are products that society views negatively and discourages the consumption of by imposing limitations, restrictions, and penalties as part of the policy aims of the government (cf. Mann \& Gairing, 2012; Musgrave, 1959; Walsh, 1987). Other examples of such products are alcoholic beverages, gambling, and prostitution.

Note 2. Wasson categorizes the market recognition of a product as a new type of product group as a "just noticeable difference" phenomenon (Wasson, 1974, p. 36). Recent researchers use the term "radical innovation" (Assink, 2006; Brexendorf, Bayus, \& Keller, 2015; Christensen \& Rosenbloom, 1995; Dahlin \& Behrens, 2005; Karande, Merchant, \& Sivakumar, 2011).

Note 3. Observations can be made based on an analysis of quantitative data regarding the nicotine products trade over an extended period. Few countries have collected quantitative data on trade in nicotine products for more than a century, and Israel is not one of them. Historical records of nicotine products sales in the United States were used in many studies for such a purpose (Giovino, 2007; Hajdu \& Vadmal, 2010; Zitzewitz, 2003). The comparison of the nicotine market in the United States to that in Europe and the Middle East is problematic, since the use of tobacco for chewing was historically the predominant category in the North American market (Cook, 2006; Hannah, 2006; Hart \& Mather, 1961), while consumers in Europe and the Middle East had a preference for pipe (Hartnett, 2004; Klioutchkine, 2009; Nourrisson, 1988; Romaniello, 2007; Shechter, 2003; Walker \& Henderson, 2010). Thus, the quantitative data from France is more suitable as a benchmark for the historical dynamic of the nicotine market in Israel. The data shown in this essay was originally published by Catherine Hill $(2004,2015)$.

Note 4 . While the combustible non-filter cigarette and the combustible filter cigarette with all its extensions can be defined as second industrial revolution products, pipe tobacco should be defined as an outcome of the commercial revolution (1100-1776), which preceded the first industrial revolution.

Note 5. Wilhelm Ruprecht suggests a different approach, differentiating between "wants" and "needs." According to Ruprecht, consumer needs are set by the individual according to his/her genetic origin and are common to human and non-human mammals. The "wants" of the individual evolve out of the personal information processing of personal knowledge about the conditional link between the satisfaction of a need and certain behaviour. Since the personal knowledge of each individual is different from that of other consumers, his/her "wants" are also unique to him/her, unless social reinforcement influences individual preference toward a certain cultural convention (Ruprecht, 2002).

Note 6. Following Coughenour's observation, two years earlier, of the necessity to separate between the decision or choice-making phase and the acquisition phase (qtd. in Klonglan \& Coward, 1970).

Note 7. The flowchart represents the process of adoption when experiencing for the first time any product from a certain product group (trying to use any nicotine product for the first time in their lives), or a certain type of products.

Note 8. Research has found that the first signs of nicotine dependence among users appear within two weeks after their first routine use of a nicotine product (DiFranza et al., 2000).

Note 9. Rogers' results regarding the proportion of each level of inclination to adopt innovativeness were also validated by Thomas Hurt, Katherine Joseph, and Chester Cock (Hurt, Joseph, \& Cook, 1977). For a more detailed discussion of each class of innovators, see: Beal and Rogers, 1958b, 1958a; Chatterjee and Eliashberg, 1990; Goldenberg, Han, Lehmann, and Hong, 2009; King and Summers, 1970; Lionberger, 1954; Lionberger and Coughenour, 1957; Rogers, 1959; Rogers and Shoemaker, 1971; Ryan and Gross, 1950; Wilkening, 1950, 1951, 1952.

Note 10. This distinction was found among JUUL users in the United States (Willett et al., 2019). Fortunately, in Hebrew, the use of an equivalent verb to "Juuling" did not evolve and it is likewise described as "vaping."

Note 11. Casual type of products aim to satisfy the user's need for nicotine without hindering other routine 
activities, such as work or street walking. Such products include combustible cigarettes, IQOS, and electronic cigarettes. Other types of nicotine products are more suited to a leisure activity, such as pipes, cigars or cigarillos, and hookahs (cf. Brandt, 2007; Hammal et al., 2008).

Note 12. In certain communities, such as ultra-orthodox youth, the alternative to conscription is the commitment is to apply to one of the institutes for advanced study of religion (a Kollel), and to remain in this full-time learning institution at least till the age of 24 (Deferral of Service for Yeshiva Students Law, first amendment 5763-2003, article 2(2)).

Note 13. It is clear, based on existing data, that the end of the sales ban at the age of 18 is not the only reason, but further research is necessary to determine these additional causes.

Note 14. Until March 8, 2019, electronic cigarette users were free from the legal limitations set on combustible cigarettes.

Note 15. In the current research, we defined as "vapers" those responders who either reported a higher duration of vaping than smoking or reported non-smoking despite using a vaporizing device (electronic cigarette or heat-not-burn tobacco product) in the last month.

Note 16. Over the years, the Israeli government kept raising taxes on tobacco manufacturing and import, and by 2015 the tax on packed cigarettes reached $80.4 \%$ of the pack cost, and $38.3 \%$ of the cost for RYO tobacco (calculated based on Israel Ministry of Health, 2018). The tax on RYO tobacco was finally raised to the tax level of packed cigarettes only on February 21, 2019 (Customs Tax and Exemptions and Purchase Tax Ordinance (fourth amendment), 5779-2019), but this tax correction occurred after six years, during which the tax for RYO tobacco was much lower than the tax on packed cigarettes. The imbalanced tax between packed cigarettes and RYO tobacco affected the average price of these two types such that the cost of RYO tobacco was much lower than the equivalent amount of packed cigarettes. The lower tax and average price of the RYO tobacco between 2012 and 2016 led to an increase in sales of $1,236 \%$; while packed cigarettes experienced only a mild increase in sales of $11.5 \%$ (Fatal, 2017). This shift from packed cigarettes to RYO tobacco due to cost was also noted in other countries, such as the United State (Agaku \& Alpert, 2016), Spain (Fu et al., 2014), the United Kingdom, France, the Netherland, and Germany (Brown et al., 2015).

Note 17. The hookah even exceeds combustible cigarettes in its prevalence in Egypt and the Palestinian Authority, which share common borders (Maziak et al., 2015).

Note 18 . The rate of hookah use in the last month among the Jewish population was extremely low, reaching only $23.1 \%$ (95\% CI $[16.89,29.34])$, probably because this product type is used for leisure in special social gatherings. The use-system of the hookah is not suitable for casual use. Therefore, this measuring tool is unsuitable for estimating the adoption rate at least for the past month.

Note 19. We define this relationship using the term "Adoption Probability," based on an equivalent term "Trial Probability" for the symbolic adoption phase (cf. Du \& Kamakura, 2011; Sinapuelas, Wang, \& Bohlmann, 2015; Steenkamp \& Gielens, 2003). Since "Trial Probability" is generally used in the context of CPG, it seems that the term "Adoption Probability" would be also more relevant for CPG than for durable goods.

Note 20. i.e., The early majority views commercial sources as unreliable (Beal \& Rogers, 1958a, 1958b), while early adopters rely on commercial information and are more commercial-oriented (Goldsmith, Flynn, \& Goldsmith, 2003; Rogers, 1959).

\section{Copyrights}

Copyright for this article is retained by the author, with first publication rights granted to the journal.

This is an open-access article distributed under the terms and conditions of the Creative Commons Attribution license (http://creativecommons.org/licenses/by/4.0/). 